\title{
ZUSES
}

\section{Hurricane Matthew: Predictions, Observations, and an Analysis of Coastal Change}

By Justin J. Birchler, Kara S. Doran, Joseph W. Long, and Hilary F. Stockdon

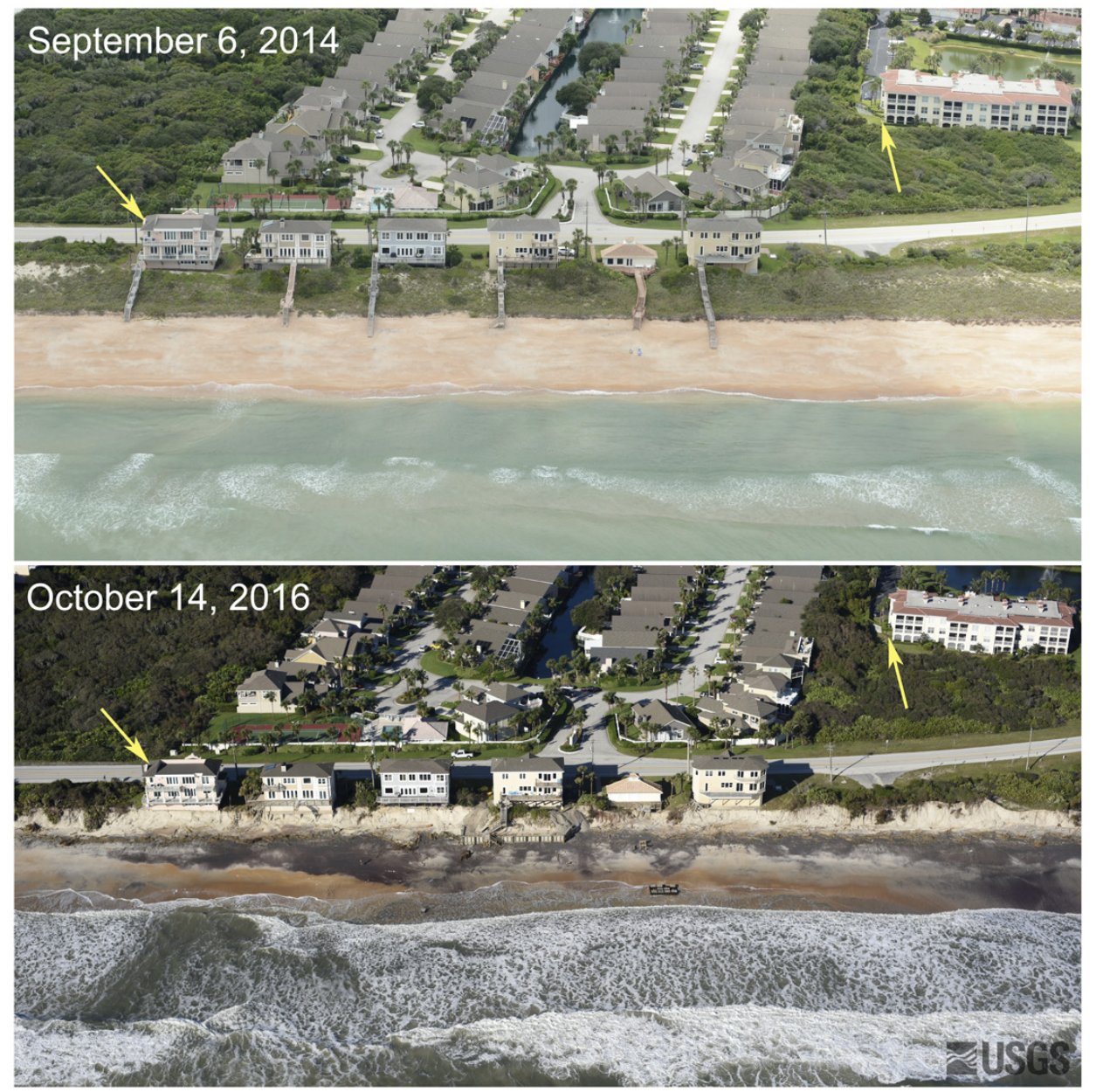

Open-File Report 2019-1095

U.S. Department of the Interior

U.S. Geological Survey 


\title{
U.S. Department of the Interior \\ DAVID BERNHARDT, Secretary
}

\author{
U.S. Geological Survey \\ James F. Reilly II, Director
}

U.S. Geological Survey, Reston, Virginia: 2019

For more information on the USGS—-the Federal source for science about the Earth, its natural and living resources, natural hazards, and the environment-visit https://www.usgs.gov/ or call 1-888-ASK-USGS (1-888-275-8747).

For an overview of USGS information products, including maps, imagery, and publications, visit https://store.usgs.gov/.

Any use of trade, firm, or product names is for descriptive purposes only and does not imply endorsement by the U.S. Government.

Although this information product, for the most part, is in the public domain, it also may contain copyrighted materials as noted in the text. Permission to reproduce copyrighted items must be secured from the copyright owner.

Suggested citation:

Birchler, J.J., Doran, K.S., Long, J.W., and Stockdon, H.F., 2019, Hurricane Matthew-Predictions, observations, and an analysis of coastal change: U.S. Geological Survey Open-File Report 2019-1095, 37 p., https://doi.org/10.3133/ ofr20191095.

Cover: Oblique aerial photographs in Vilano Beach, Florida, collected before (top) and after (bottom) Hurricane Matthew. Storm waves and currents eroded sand dunes and exposed previously buried building foundations. The yellow arrows in each image point to the same buildings in both photos. 


\section{Acknowledgments}

The U.S. Geological Survey (USGS) National Assessment of Coastal Change Hazards Project would like to thank the U.S. Army Corps of Engineers Joint Airborne Lidar Bathymetry Technical Center of Expertise for the post-storm data collection effort. We would also like to thank the many scientists and support staff who invested long hours during the 2016 hurricane season. Specifically, we thank our colleagues in the USGS in St. Petersburg-Xan Fredericks, Nathaniel Plant, and Jolene Gittens-for their invaluable contributions to the Hurricane Matthew effort. We thank the USGS Caribbean-Florida and South Atlantic Water Science Centers for their assistance with data collection.

This Open-File Report is part of a succession of reports (Hurricane [Name of storm]: Predictions, Observations, and an Analysis of Coastal Change) about hurricanes in the western Atlantic Ocean and the Caribbean Sea, and it includes descriptions of storm conditions and effects. As a series, there is a common language used for consistency and ease of comparison from storm to storm and year to year. 


\section{Contents}

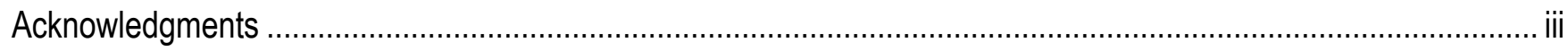

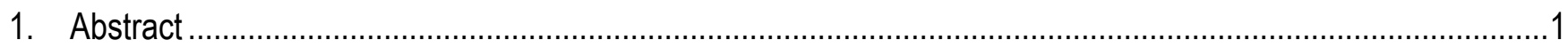

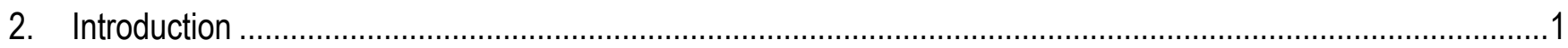

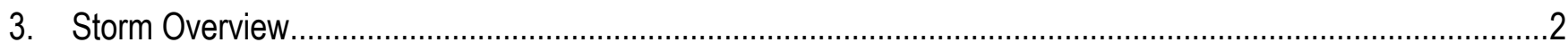

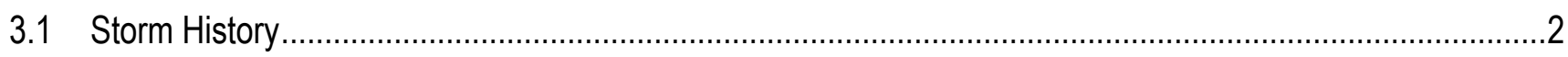

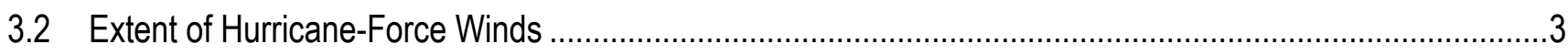

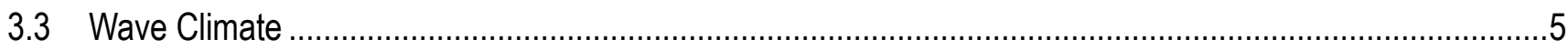

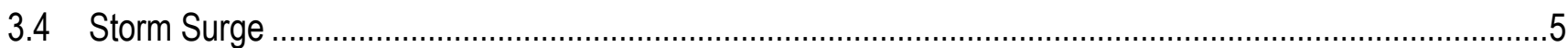

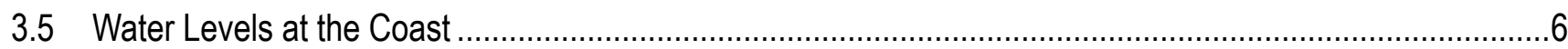

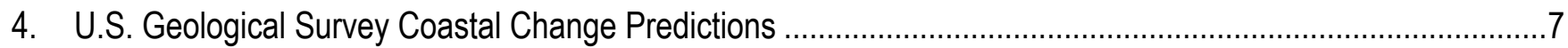

5. U.S. Geological Survey Coastal-Change Observations ...........................................................................

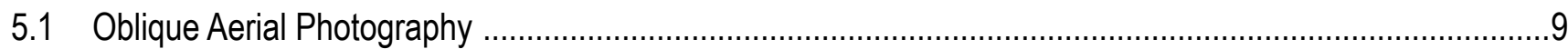

5.2 Airborne Lidar Topographic Surveys ..........................................................................................

5.3 Overwash Delineation ............................................................................................................. 11

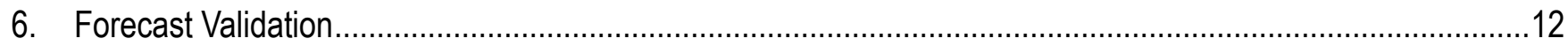

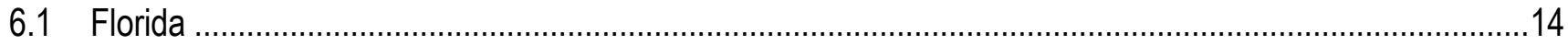

6.2 Georgia

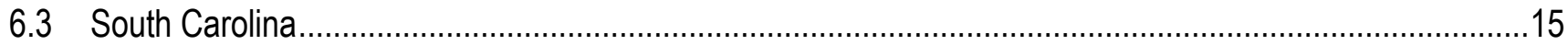

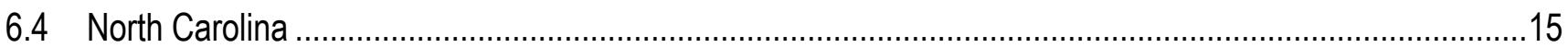

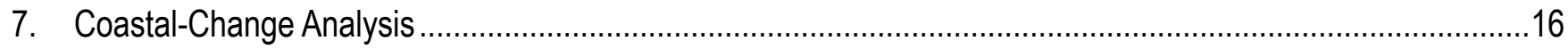

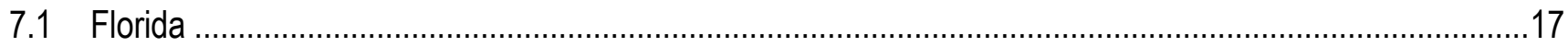

7.2 Georgia

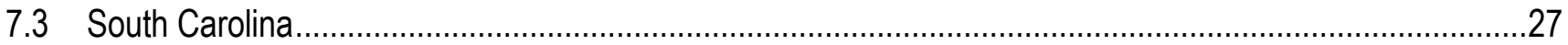

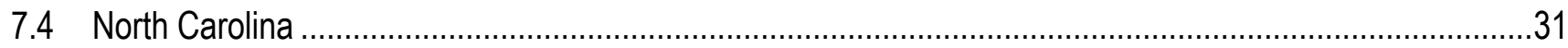

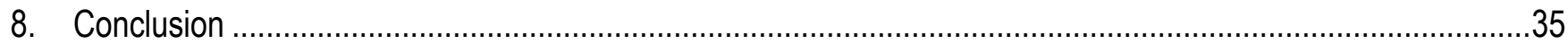

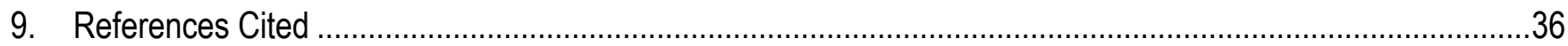

\section{Figures}

1. Map showing Hurricane Matthew track and intensity, moored National Oceanic and Atmospheric

Administration buoys recording wave height and period, NOAA tide stations recording tide and surge, and U.S. Geological Survey sensors recording stormwater levels.

2. Map showing the maximum sustained wind speeds generated by Hurricane Matthew, as calculated by the National Oceanic and Atmospheric Administration National Hurricane Center. 
3. Graph showing: $A$, significant wave height and $B$, dominant wave period during the passage of Hurricane Matthew, as measured by National Oceanic and Atmospheric Administration National Data Buoy Center buoys.

4. Graph showing storm surge determined by the tidal residual, equal to the measured tide level minus the predicted tide level.

5. Graph showing water levels measured by U.S. Geological Survey rapidly deployed storm-tide and waveheight sensors on beaches in Florida, Georgia, South Carolina, and North Carolina along the track of Hurricane Matthew ....

6. Screen-capture image of Hurricane Matthew pre-storm forecast probabilities of coastal change from the Coastal Change Hazards Portal updated 1200 Coordinated Universal Time October 7, 2016, National Hurricane Center Advisory 37.

7. Map showing Hurricane Matthew pre- and post-storm aerial photography, left; and airborne lidar coverage, right.

8. Aerial imagery of Cape Canaveral, Florida, $A, C, E$; and St. Augustine, Florida, $B, D, F$.

9. Map showing Hurricane Matthew overwash extent delineations and breach locations for Florida through North Carolina.

10. Combination histograms showing Hurricane Matthew: $A$, dune elevation change; $B$, pre- and poststorm dune elevation; $C$, shoreline change, and $D$, beach volume change between May 2016 and November 2016 for the Florida coast.

11. Combination graphs showing Hurricane Matthew: $A$, dune elevation change; $B$, pre- and post-storm dune elevation; $C$, shoreline change, and $D$, beach volume change between May 2016 and November 2016 for the southern portion of the Florida Atlantic coast.

12. Combination graphs showing Hurricane Matthew: $A$, dune elevation change; $B$, pre- and post-storm dune elevation $C$, shoreline change, and $D$, beach volume change between May 2016 and November 2016 for the northern portion of the Florida Atlantic coast.

13. Maps showing Hurricane Matthew: $A$, dune elevation change; $B$, pre- and post-storm dune elevation; $C$, shoreline change, and $D$, beach volume change between May 2016 and November 2016 for the southern portion of the Florida Atlantic coast.....

14. Maps showing Hurricane Matthew: $A$, dune elevation change; $B$, pre- and post-storm dune elevation; $C$, shoreline change, and $D$, beach volume change between May 2016 and November 2016 for the northern portion of the Florida Atlantic coast.

15. Combination histograms showing Hurricane Matthew: $A$, dune elevation change; $B$, pre- and poststorm dune elevation darker color indicates overlap of the two distributions; $C$, shoreline change, and $D$, beach volume change between May 2010 and November 2016 for the Georgia coast.

16. Combination graphs showing Hurricane Matthew: $A$, dune elevation change; $B$, pre- and post-storm dune elevation; $C$, shoreline change, and $D$, and beach volume change between May 2010 and November 2016 for the Georgia coast

17. Maps showing Hurricane Matthew: $A$, dune elevation change; $B$, pre- and post-storm dune elevation; $C$, shoreline change, and $D$, beach volume change between May 2010 and November 2016 for the Georgia coast.

18. Combination histograms showing Hurricane Matthew: $A$, dune elevation change; $B$, pre- and post-storm dune elevation darker color indicates overlap of the two distributions; $C$, shoreline change, and $D$, beach volume change between May 2010 and November 2016 for the South Carolina coast 
19. Combination graphs showing Hurricane Matthew: $A$, dune elevation change; $B$, pre- and post-storm dune elevation; $C$, shoreline change, and $D$, beach volume change between May 2010 and November 2016 for the South Carolina coast.

20. Maps showing Hurricane Matthew: $A$, dune elevation change; $B$, pre- and post-storm dune elevation; $C$, shoreline change, and $D$, beach volume change between May 2010 and November 2016 for the South Carolina coast

21. Combination histograms showing Hurricane Matthew: $A$, dune elevation change; $B$, pre- and post-storm dune elevation darker color indicates overlap of the two distributions; $C$, shoreline change, and $D$, beach volume change between January 2014 and November 2016 for the North Carolina coast.....

22. Combination graphs showing Hurricane Matthew: $A$, dune elevation change; $B$, pre- and post-storm dune elevation; $C$, shoreline change, and $D$, beach volume change between January 2014 and November 2016 for the North Carolina coast

23. Maps showing Hurricane Matthew: $A$, dune elevation change; $B$, pre- and post-storm dune elevation; $C$, shoreline change, and $D$, beach volume change between January 2014 and November 2016 for the North Carolina coast.

\section{Tables}

1. Forecast prediction of the percentage of sandy coast very likely to experience coastal change during Hurricane Matthew

2. Details of the pre- and post-storm photography collection used for qualitative analysis of coastal-change and quantitative visual overwash delineation.

3. Details of the pre- and post-storm lidar data used for quantitative coastal-change analysis

4. Contingency table for Florida showing the number of locations where overwash was and was not predicted alongside corresponding locations where overwash was and was not observe....

5. Contingency table for Georgia showing the number of locations where overwash was and was not predicted and corresponding locations where overwash was and was not observed.

6. Contingency table for South Carolina showing the number of locations where overwash was and was not predicted and corresponding locations where overwash was and was not observed

7. Contingency table for North Carolina showing the number of locations where overwash was and was not predicted and corresponding locations where overwash was and was not observed..... 


\section{Conversion Factors}

International System of Units to U.S. customary units

\begin{tabular}{|c|c|c|}
\hline Multiply & By & To obtain \\
\hline \multicolumn{3}{|c|}{ Length } \\
\hline centimeter $(\mathrm{cm})$ & 0.3937 & inch (in.) \\
\hline millimeter $(\mathrm{mm})$ & 0.03937 & inch (in.) \\
\hline meter $(\mathrm{m})$ & 3.281 & foot $(\mathrm{ft})$ \\
\hline kilometer $(\mathrm{km})$ & 0.6214 & mile (mi) \\
\hline kilometer (km) & 0.5400 & mile, nautical (nmi) \\
\hline meter $(\mathrm{m})$ & 1.094 & yard (yd) \\
\hline \multicolumn{3}{|c|}{ Area } \\
\hline square meter $\left(\mathrm{m}^{2}\right)$ & 0.0002471 & acre \\
\hline square kilometer $\left(\mathrm{km}^{2}\right)$ & 247.1 & acre \\
\hline square meter $\left(\mathrm{m}^{2}\right)$ & 10.76 & square foot $\left(\mathrm{ft}^{2}\right)$ \\
\hline square kilometer $\left(\mathrm{km}^{2}\right)$ & 0.3861 & square mile $\left(\mathrm{mi}^{2}\right)$ \\
\hline \multicolumn{3}{|c|}{ Volume } \\
\hline cubic meter $\left(\mathrm{m}^{3}\right)$ & 35.31 & cubic foot $\left(\mathrm{ft}^{3}\right)$ \\
\hline cubic meter $\left(\mathrm{m}^{3}\right)$ & 1.308 & cubic yard $\left(\mathrm{yd}^{3}\right)$ \\
\hline \multicolumn{3}{|c|}{ Flow rate } \\
\hline kilometer per hour $(\mathrm{km} / \mathrm{h})$ & 0.6214 & mile per hour $(\mathrm{mi} / \mathrm{h})$ \\
\hline kilometer per hour $(\mathrm{km} / \mathrm{h})$ & 0.5400 & Knots (kt) \\
\hline
\end{tabular}

\section{Datum}

Vertical coordinate information is referenced to the North American Vertical Datum of 1988 (NAVD 88).

Horizontal coordinate information is referenced to the North American Datum of 1983 (NAD 83).

\section{Abbreviations}

$\begin{array}{ll}\text { CHARTS } & \text { Compact Hydrographic Airborne Rapid Total Survey } \\ \text { CORS } & \text { Continuously Operating Reference Stations } \\ \text { DEM } & \text { digital elevation model } \\ \text { DFL } & \text { distance from landfall } \\ \text { GPS } & \text { Global Positioning System } \\ \text { Hs } & \text { significant wave height } \\ \text { JALBTCX } & \text { Joint Airborne Lidar Bathymetry Technical Center of Expertise } \\ \text { km } & \text { kilometers } \\ \text { km/h } & \text { kilometers per hour } \\ \text { lidar } & \text { light detection and ranging } \\ \text { m } & \text { meters } \\ \text { NACCH } & \text { National Assessment of Coastal Change Hazards } \\ \text { NAD83 } & \text { North American Datum of 1983 } \\ \text { NAVD88 } & \text { North American Vertical Datum of 1988 } \\ \text { NDBC } & \text { National Data Buoy Center } \\ \text { NGS } & \text { National Geodetic Survey }\end{array}$




$\begin{array}{ll}\text { NHC } & \text { National Hurricane Center } \\ \text { NOS } & \text { National Ocean Service } \\ \text { NOAA } & \text { National Oceanic and Atmospheric Administration } \\ \text { NWC } & \text { National Weather Center } \\ \text { NWS } & \text { National Weather Service } \\ \text { P-Surge } & \text { Probabilistic Tropical Cyclone Storm Surge model } \\ \text { S } & \text { seconds } \\ \text { SLOSH } & \text { Sea, Lake, and Overland Surges from Hurricanes } \\ \text { Td } & \text { dominant wave period } \\ \text { USACE } & \text { U.S. Army Corps of Engineers } \\ \text { USGS } & \text { U.S. Geological Survey } \\ \text { UTC } & \text { Coordinated Universal Time } \\ \text { WGS84 } & \text { World Geodetic System 1984 }\end{array}$




\title{
Hurricane Matthew: Predictions, Observations, and an Analysis of Coastal Change
}

\author{
By Justin J. Birchler, Kara S. Doran, Joseph W. Long, and Hilary F. Stockdon
}

\section{Abstract}

Hurricane Matthew, the strongest Atlantic hurricane of the 2016 hurricane season, made landfall south of McClellanville, S.C., around 1500 Coordinated Universal Time (UTC) on October 8, 2016. Hurricane Matthew affected the States of Florida, Georgia, South Carolina, and North Carolina along the U.S. Atlantic coastline. Numerous barrier islands were breached, and the erosion of beaches and dunes occurred along most of the South Atlantic coast. The U.S. Geological Survey (USGS) forecasted potential coastal-change effects - including dune erosion and overwash that can threaten coastal resources and infrastructure - to assist with pre-storm management decisions. Following the storm, oblique aerial photography was collected, and lidar topographic survey missions were flown. These two datasets were used to document the changes that resulted from the storm and to validate coastal change forecasts. Comparisons of pre- and post-storm photographs were used to characterize the nature, extent, and spatial variability of hurricane-induced coastal changes. Analyses of pre- and post-storm lidar elevations were used to quantify magnitudes of change in shoreline positions, dune elevations, and beach volumes. Erosion was observed along the coast from Florida to North Carolina; however, the coastal response exhibited extensive spatial variability, as would be expected over such a large region.

\section{Introduction}

The U.S. Geological Survey (USGS) National Assessment of Coastal Change Hazards (NACCH) project (https:/www.usgs.gov/natural-hazards/coastal-marine-hazards-and-resources/science/ national-assessment-coastal-change-hazards) provides actionable information about the Nation's coastlines to help residents of coastal areas, government agencies responsible for coastal management, and coastal researchers. Extreme storms are one category among the many hazards that affect coastal environments. Hurricanes, nor'easters, and Pacific winter storms are powerful events that generate dangerous waves and surges that move large amounts of sand, destroy buildings and infrastructure, and take lives. Processes such as dune erosion, overwash, and inundation allow storms to reshape portions of the Nation's coastlines in a matter of hours. The storm-induced erosion hazards mission of NACCH (https:// www.usgs.gov/centers/spcmsc/science/national-assessment-storm-induced-coastal-change-hazards) is focused on quantifying and understanding the magnitude and variability of effects that extreme storms have on sandy beaches. The information gained from these studies can lead to improvements in the real-time and scenario-based predictions of coastal change while supporting the management of coastal infrastructure, resources, and safety practices.

Understanding storm-induced coastal change well enough to forecast changes requires knowledge of the physical processes associated with storms and the geomorphology of the affected coastline. The primary oceanographic forces that drive coastal change during storms are waves and storm surge. Storm surge, a rise in water level due to wind, barometric pressure, and other factors, allows waves and currents to affect parts of the upper beach and dunes that are not normally exposed to these processes. The 
morphology of coastal features, particularly the primary sand-dune elevation, beach width, and slope, are compared to the storm-elevated waves and water levels, which allows researchers to define the vulnerability of these features during a storm event.

The three critical elements of this work are (1) the forecast of potential coastal-change effects for emergency planning, (2) the use of direct observations of coastal change to determine the accuracy of the forecast, and (3) update the coastal elevations (for example, the post-storm dune elevations) for future storm forecasts. Immediately after Hurricane Matthew made landfall, Federal agencies responded with a large-scale data collection effort that included oblique aerial photography, airborne topographic surveys, and ground-based topographic surveys. This report documents USGS efforts to assess the effects of Hurricane Matthew along the Atlantic coast. Qualitative and quantitative observations of hurricane-induced changes to the shoreline, beaches, and dunes are presented for the region most heavily affected by the storm. The potential causes behind the spatial variations in the observed response are outside of the scope of this report and may be addressed in other scientific reports.

This report is divided into the following primary sections:

- Section 3, Storm Overview_presents a synopsis of the storm, including meteorological evolution, wind speed impact area, wind-wave generation, and storm-surge extent and magnitudes.

- Section 4, Coastal-Change Predictions-describes the predicted effects to the coasts along the affected areas.

- Section 5, Coastal-Change Observations - describes data collection missions, including the acquisition of oblique aerial photography and airborne light detection and ranging (lidar) topographic surveys, and observations of coastal change in response to Hurricane Matthew.

- Section 6, Forecast Validation - compares the coastal change forecast with observations of coastal change.

- Section 7, Coastal-Change Analysis - describes data-analysis methods and results.

\section{Storm Overview}

\subsection{Storm History}

Hurricane Matthew was an active tropical weather system in the North Atlantic Ocean and the Caribbean Sea from September 28 to October 9, 2016 (fig. 1; Stewart, 2017). Based on estimates made using Air Force Reserve Hurricane Hunter aircraft wind data and microwave satellite imagery, Tropical Storm Matthew formed at about 1200 Coordinated Universal Time (UTC) on September 28, at a location 28 kilometers $(\mathrm{km})$ west-northwest of Barbados (Stewart, 2017). As the tropical storm moved westward into the warm waters of the Caribbean Sea, gradual strengthening occurred, and Tropical Storm Matthew became Hurricane Matthew at 1800 UTC on September 29. The hurricane rapidly intensified over a 24-hour period, and at 0000 UTC, on October 1, became a Category 5 hurricane, reaching peak intensity with winds of 269 kilometers per hour $(\mathrm{km} / \mathrm{h})$. Turning north, Hurricane Matthew made landfall along the southwestern coast of Haiti around 1100 UTC on October 4 as a Category 4 hurricane with winds of $241 \mathrm{~km} / \mathrm{h}$. Matthew continued north and made landfall along the eastern end of Cuba at 0000 UTC on October 5 as a Category 4 hurricane with winds of $231 \mathrm{~km} / \mathrm{h}$. At around 0000 UTC on October 7, the storm moved northwest and made landfall near West End, Grand Bahama Island, The Bahamas. Matthew gradually weakened as it approached the United States and subsequently moved 
along the Florida coast. The hurricane continued north, hugging the coasts of Florida, Georgia, and South Carolina while continuing to weaken.

Hurricane Matthew was a Category 1 storm with maximum sustained winds of $139 \mathrm{~km} / \mathrm{h}$ when it made landfall at about 1500 UTC on October 8, south of McClellanville, S.C., within the Cape Romain National Wildlife Refuge. The center of the hurricane moved back offshore by 1800 UTC on October 8 and traveled northeast, offshore of the North Carolina coast. The storm lost its tropical characteristics by 1200 UTC on October 9, although hurricane-force winds were still present.

\subsection{Extent of Hurricane-Force Winds}

The maximum sustained winds from Hurricane Matthew were estimated by the National Oceanic and Atmospheric Administration (NOAA) Atlantic Oceanographic and Meteorological Laboratory, Hurricane Research Division (using methods described by Powell and others [1998]). Hurricane-force

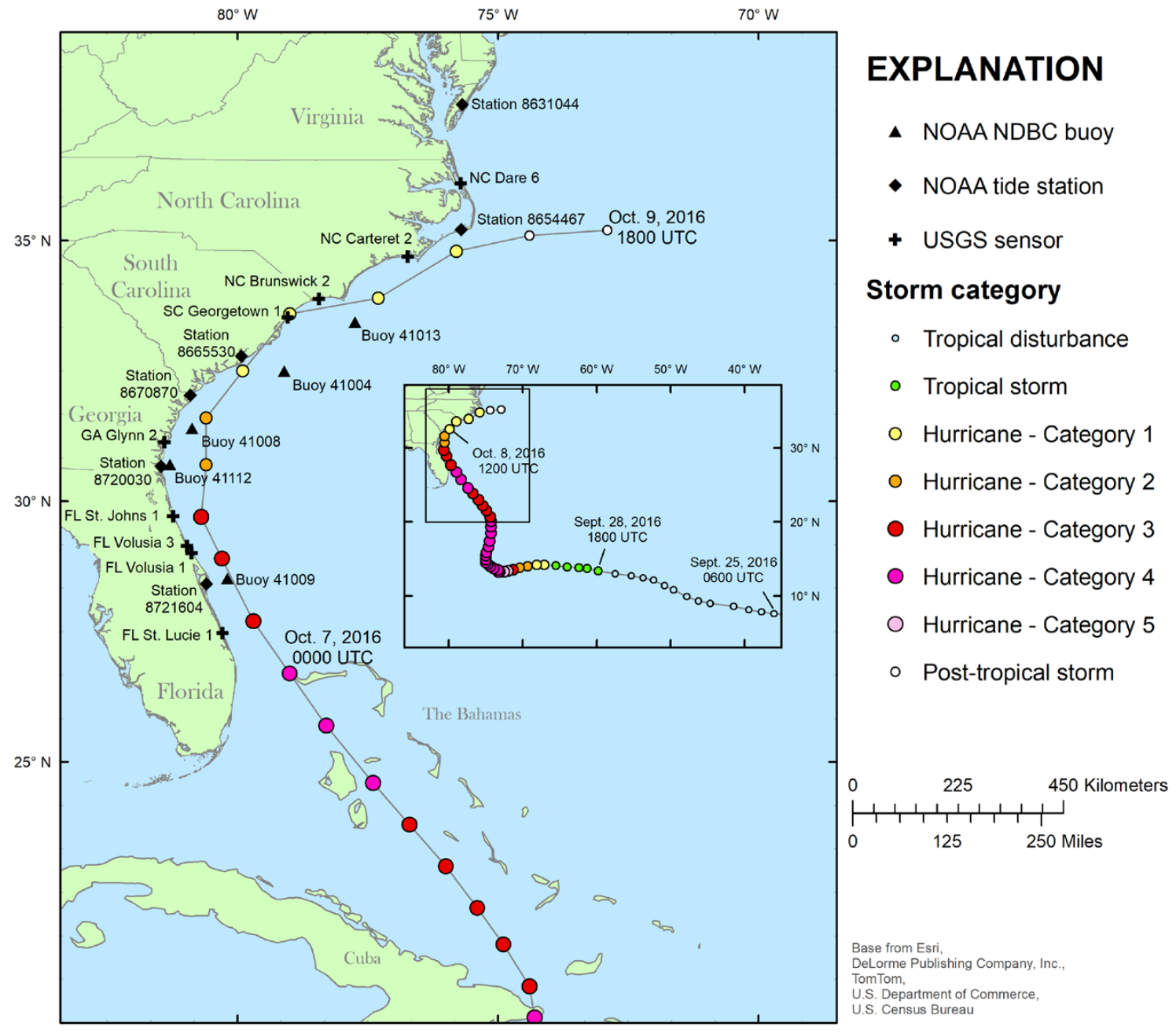

Figure 1. Map showing Hurricane Matthew track and intensity, moored National Oceanic and Atmospheric Administration (NOAA) National Data Buoy Center (NDBC) buoys recording wave height and period, NOAA tide stations recording tide and surge, and U.S. Geological Survey (USGS) sensors recording stormwater levels. The inset map shows the entire track of Hurricane Matthew. 
winds affected over $300 \mathrm{~km}$ of the Florida coastline between Fort Pierce and Ponte Vedra Beach and approximately $175 \mathrm{~km}$ of the South Carolina coastline between Charleston and the North Carolina border (fig. 2). These hurricane-force winds were mainly confined to immediate coastal areas and barrier islands in these areas (fig. 2). Tropical storm force winds reached at least $130 \mathrm{~km}$ inland as Hurricane Matthew tracked up the Atlantic coast from Florida to North Carolina (Stewart, 2017). The strongest winds were measured at Kennedy Space Center at Cape Canaveral, Fla.; sustained winds of 119-137 km/h, with gusts of 169-172 km/h, were measured (Stewart, 2017). A National Weather Service (NWS) damage survey indicated that Category 2 sustained winds likely occurred in the coastal areas of northern Brevard County, Fla., although no measurements exist in this location to definitively confirm this analysis (Stewart, 2017).

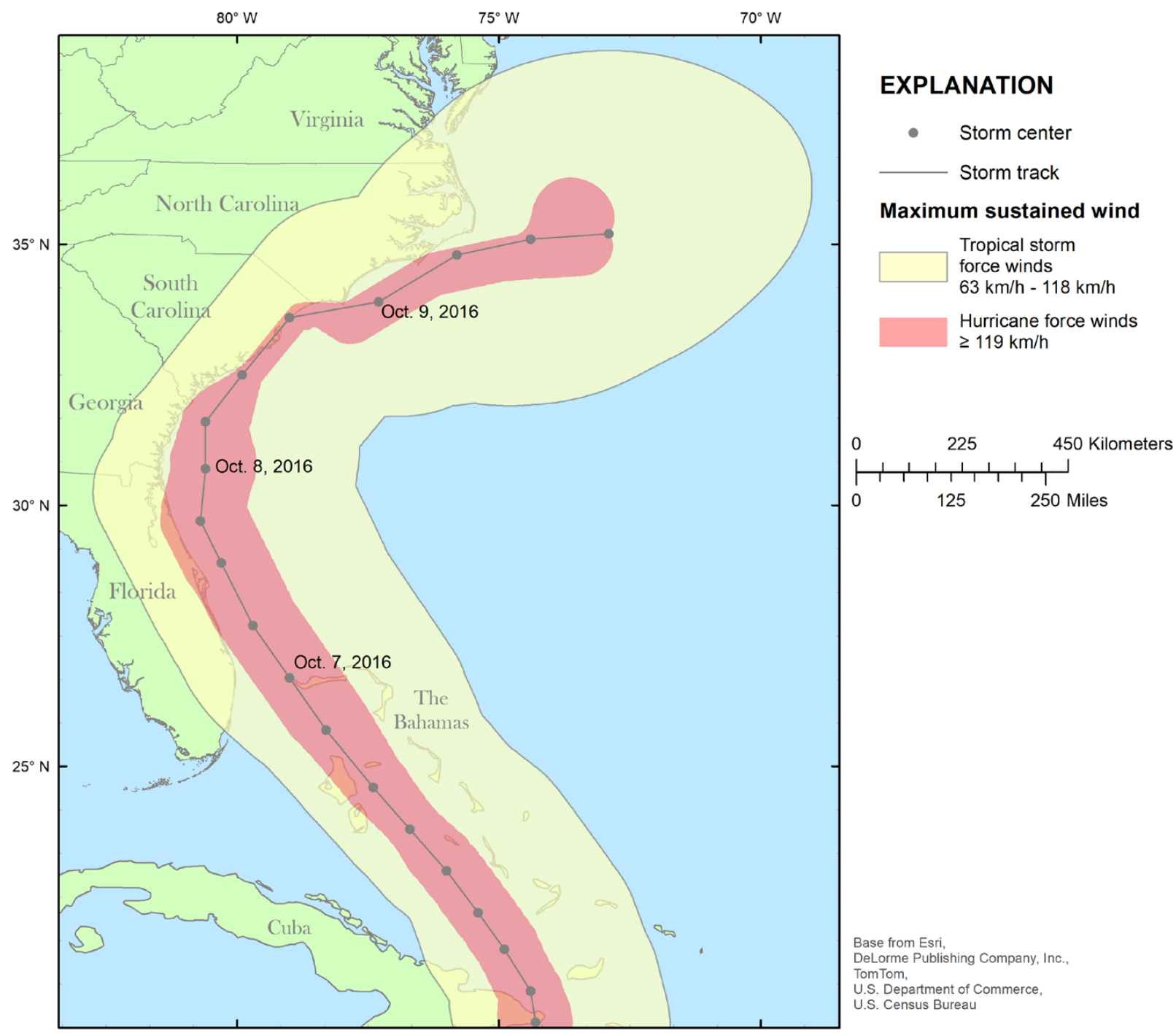

Figure 2. Map showing the maximum sustained wind speeds generated by Hurricane Matthew, as calculated by the National Oceanic and Atmospheric Administration (NOAA) National Hurricane Center (NHC). The extent of hurricane-force winds, as defined by a Category 1 wind speed of 119 kilometers per hour $(\mathrm{km} / \mathrm{h})$, is indicated by the light red contour. 


\subsection{Wave Climate}

Several moored buoys (figs. 1, 3) operated by the NOAA National Data Buoy Center (NDBC) measured the significant wave height (Hs) and dominant wave period (Td) of waves generated by Hurricane Matthew. Buoy 41009, offshore of Cape Canaveral, Fla., was located directly in the path of Hurricane Matthew; the buoy became unmoored around 0539 UTC on October 7 and measured a maximum Hs of 5.2 meters (m) at that time. Buoy 41004, offshore of Charleston, S.C., measured the largest Hs of $7.7 \mathrm{~m}$ at 1250 UTC on October 8 as Hurricane Matthew passed $60 \mathrm{~km}$ to the west. The maximum Hs at Buoy 41112 near Fernandina Beach, Fla., was $6.0 \mathrm{~m}$ at 2101 UTC on October 7. The maximum Hs at Buoy 41008 near Savannah, Ga., was $5.9 \mathrm{~m}$ at 0250 UTC on October 8. The maximum Hs at Buoy 41013 near Frying Pan Shoals, N.C., was $6.5 \mathrm{~m}$ at 1650 UTC on October 8. The maximum Td varied between 12.9 and 13.3 seconds (s) among the four buoys that remained operational for the duration of the storm.

\subsection{Storm Surge}

Measurements of storm surge are primarily gathered from coastal tide gages and land-based storm sensors and high-water marks (McCallum and others, 2013). During Hurricane Matthew, many tide gages were operational, and data from these gages were published by Stewart (2017) and the NOAA
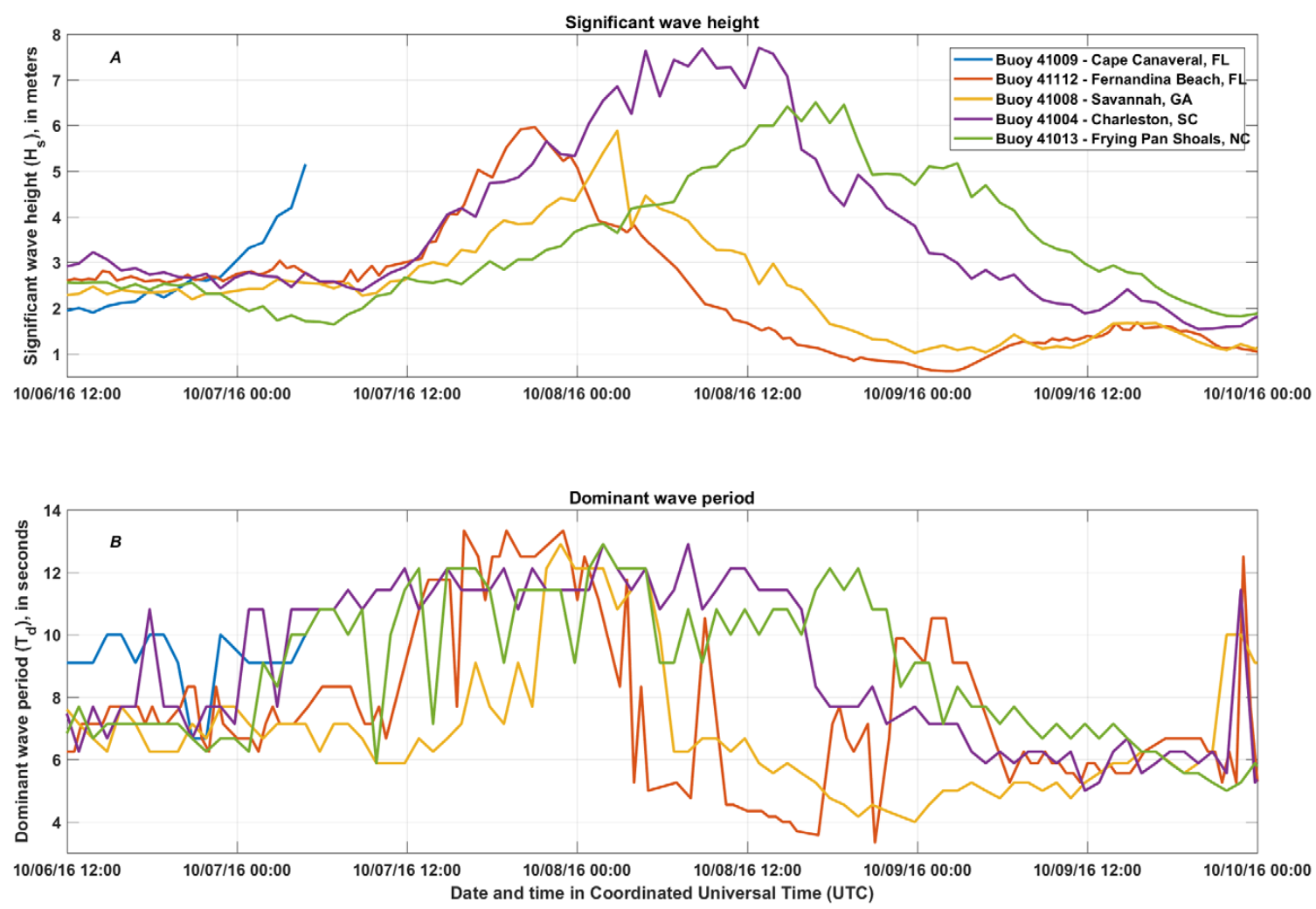

Figure 3. Graph showing $(A)$ significant wave height and $(B)$ dominant wave period during the passage of Hurricane Matthew, as measured by National Oceanic and Atmospheric Administration (NOAA) National Data Buoy Center (NDBC) buoys 41004, 41008, 41009, 41013 and 41112 (see fig. 1 for buoy locations). 
National Ocean Service (NOS) (2017). Higher than normal water levels, driven by Matthew's vast wind field, affected the southeast and mid-Atlantic coast (fig. 4). The gage at Fernandina Beach, Fla., recorded water levels $2.12 \mathrm{~m}$ above the normal tide level, and a gage at Fort Pulaski National Monument, Ga., recorded water levels $2.34 \mathrm{~m}$ above the normal tide level. Gages located at Charleston, S.C., and Hatteras, N.C., measured water levels of $1.89 \mathrm{~m}$ and $1.85 \mathrm{~m}$ above normal, respectively (Stewart, 2017).

\subsection{Water Levels at the Coast}

Prior to Hurricane Matthew, the USGS deployed more than 284 storm tide sensors along the coast from Florida to North Carolina. The sensors were installed on bridges, piers, and other structures. Sensors were deployed at various elevations above the normal water level to capture storm-induced water levels. Some sensors were lost or malfunctioned, while others remained above the elevated water level where they could not record data. A majority of the sensors remained operational and recorded water level data during the storm; this deployment was described in detail by Frantz and others (2017), and data from the deployment are accessible through the USGS Flood Event Viewer (https://stn.wim. usgs.gov/FEV/\#MatthewOctober2016). Higher than normal water levels were observed at representative sensors located between dunes and the Atlantic Ocean (fig. 5). These data were filtered to reduce noise upon recovery and to improve display clarity in figure 5. The maximum water level after the initial filtering is reported here. The sensor at St. Simons Pier in Glynn County, Ga., (GAGLY18414) recorded the highest water levels, which were $3.27 \mathrm{~m}$ above NAVD88. At Fort Matanzas National Monument beach in St. Johns County, Fla., (FLSTJ03126), water levels of 2.56 m NAVD88 were recorded. The

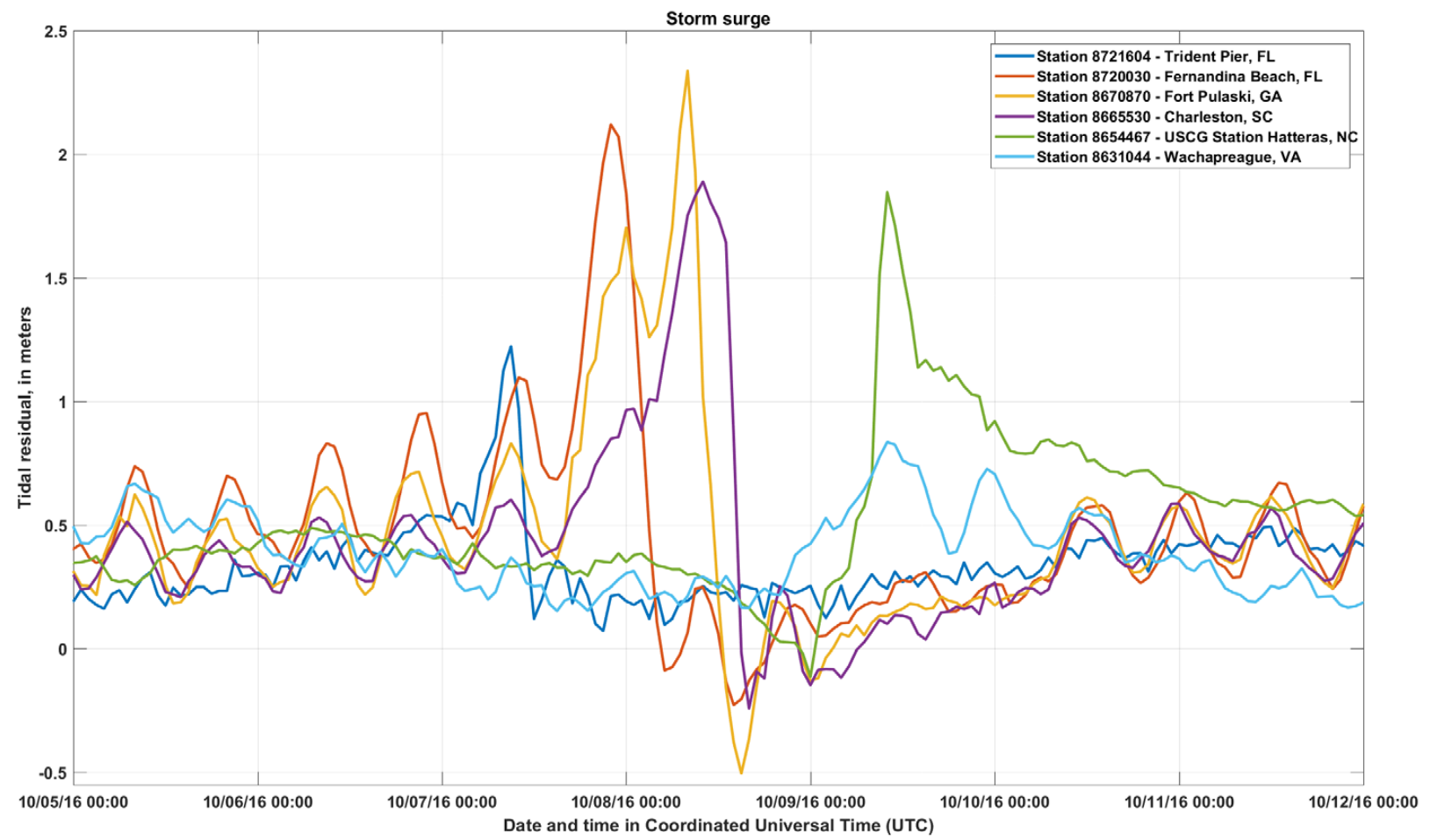

Figure 4. Graph showing storm surge determined by the tidal residual, equal to the measured tide level minus the predicted tide level. Storm surge during the passage of Hurricane Matthew was measured along the coast by National Oceanic and Atmospheric Administration (NOAA) tide stations, listed south to north (see figure explanation; see fig. 1 for tide station locations). 
maximum water levels at each sensor location moved forward in time from south to north, consistent with the movement of the storm. Note that the sensors could not measure water level elevations below the sensor height; therefore, the horizontal line shown in the time series before-after-between peaks for the sensors denote the sensor elevation and not the actual water level.

\section{U.S. Geological Survey Coastal Change Predictions}

The USGS National Assessment of Coastal Change Hazards project often forecasts the probability of different types of coastal change associated with storm events to better understand potential storm effects along the coast and thereby aid management decisions. The decision to produce a forecast is triggered by several factors, including whether the expected storm event has a high likelihood of causing significant coastal change, whether significant societal or ecosystem effects are expected, and whether overlaps with ongoing research or applied efforts are occurring. The probability of the expected type of coastal change is forecast by comparing modeled elevations of storm-induced water levels to known elevations of coastal topography. Forecasts of the effects of a landfalling storm are disseminated through the USGS Coastal Change Hazards Portal (https://marine.usgs.gov/coastalchangehazardsportal/) (fig. 6).

During a storm, the combined effects of (1) the astronomical tide, (2) storm surge, and (3) wave runup (both setup and swash) move the erosive forces of the storm higher on the beach than during typical wave conditions. The predicted peak surge values were obtained from the NOAA NWS Probabilistic

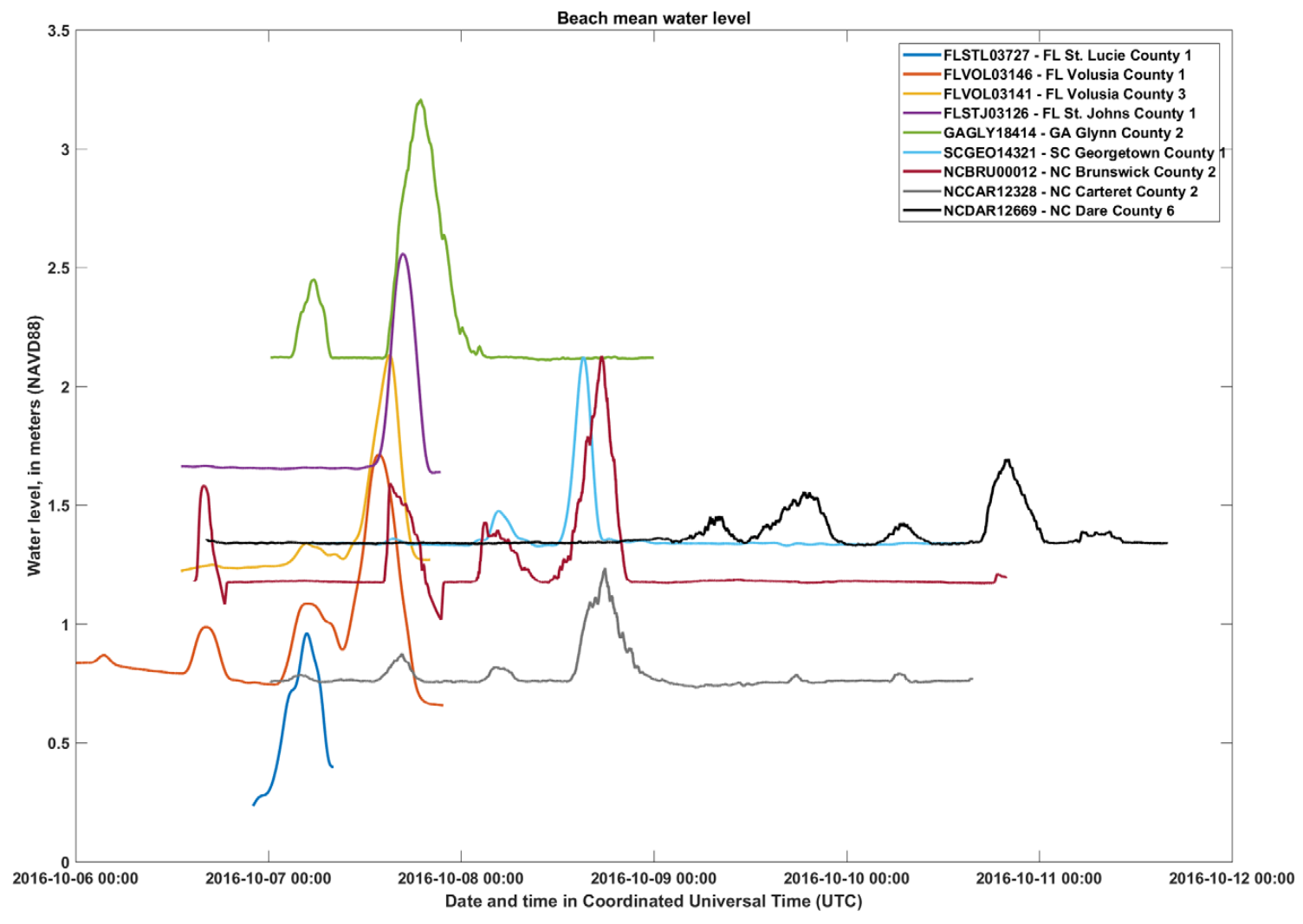

Figure 5. Graph showing water levels measured by U.S. Geological Survey rapidly deployed storm-tide and wave-height sensors on beaches in Florida, Georgia, South Carolina, and North Carolina along the track of Hurricane Matthew. Stations are listed south to north (see the explanation and fig. 1 for station locations). 
Hurricane Storm Surge (P-Surge) model, which is based on conditions specific to the landfalling storm. The P-Surge model uses an ensemble approach of the Sea, Lake, and Overland Surges from Hurricanes (SLOSH) model. This approach includes error statistics from past hurricane forecasts and uncertainties in hurricane track, size, forward speed, and intensity to determine probable storm surge elevations at locations near the storm within the next 102 hours. The 10 percent exceedance surge level represents a reasonable worst-case scenario. Wave runup elevations at the shoreline were computed using the Stockdon parameterization (Stockdon and others, 2006, 2012) with the last measured beach slope (dune toe to shoreline), and maximum significant wave heights and peak periods at 20-m water depth obtained from the NOAA Environmental Modeling Center WaveWatch III model 7-day forecast.

The three regimes used to characterize potential effects include dune erosion (collision), dune overwash, and inundation (Sallenger, 2000; Stockdon and others, 2007). Collision with the dune occurs when the extreme water level exceeds the elevation of the dune base. Overwash occurs when the extreme water level exceeds the elevation of the dune crest. Inundation occurs when the mean water level and the sum of the tide, surge, and wave setup exceeds the elevation of the dune crest. If none of these conditions are met, the beach is in the swash regime, meaning it is within a range where waves affect the foreshore and backshore environments but not the protective sand dunes.

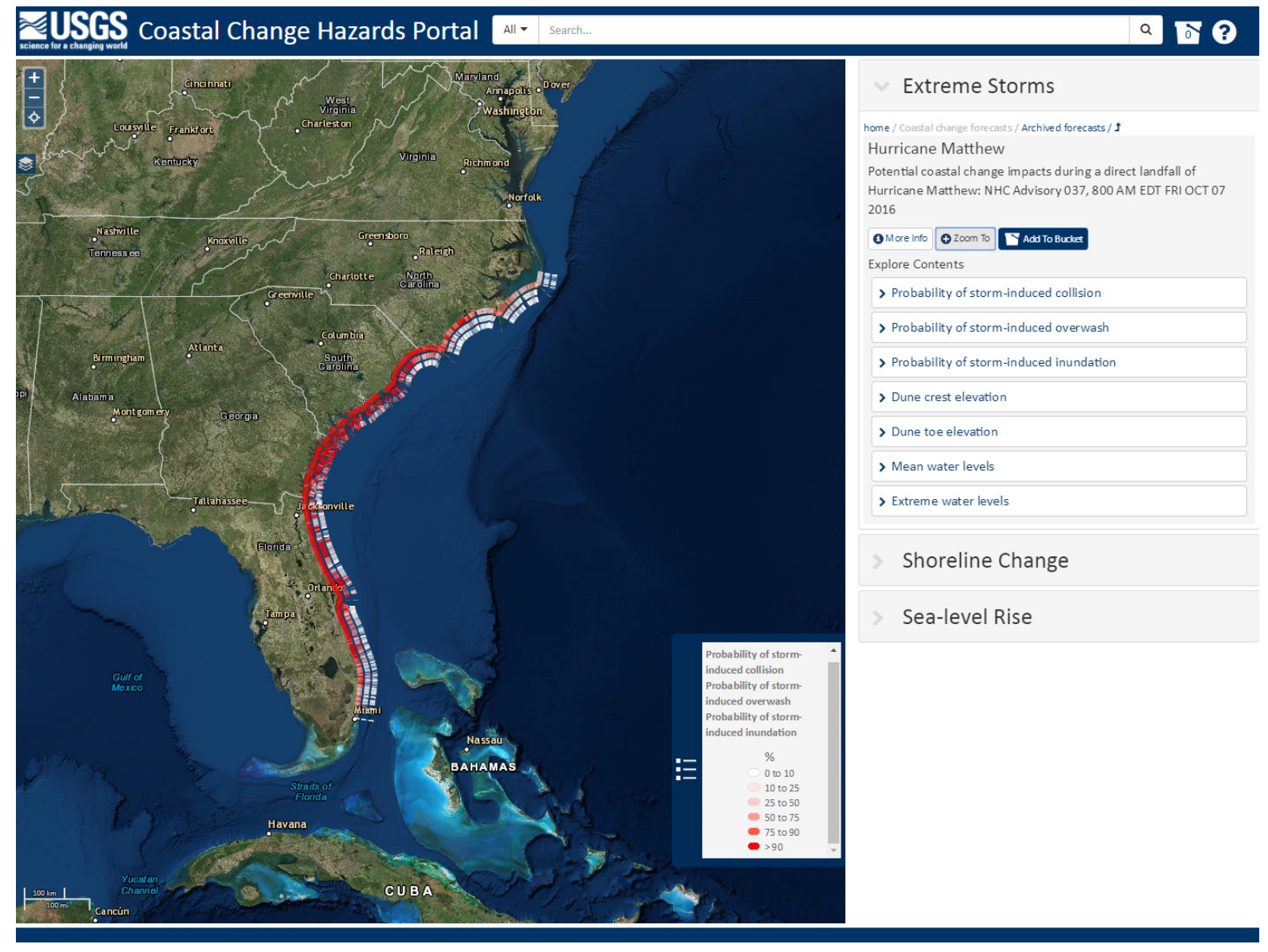

Figure 6. Screen-capture image of Hurricane Matthew pre-storm forecast probabilities of coastal change from the Coastal Change Hazards Portal updated 1200 Coordinated Universal Time (UTC) October 7, 2016, National Hurricane Center (NHC) Advisory 37 (http://marine.usgs.gov/coastalchangehazardsportal/). The three alongshore lines show (from left to right) probabilities of collision, overwash, and inundation, respectively. The color white denotes a low probability of change to dunes, and dark red shows a high probability of change to dunes. Florida calculations based on 2009-2010 data available during the storm. 
Prior to Hurricane Matthew making landfall, the probability of coastal change was determined for the sandy coasts of Florida, Georgia, South Carolina, and North Carolina (fig. 6). The forecast covered $1430 \mathrm{~km}$ of open-coast beaches along the Atlantic mainland and barrier islands. This section of coast was forecast to be very likely (probability $>90$ percent) to experience collision for $996 \mathrm{~km}$ of coast (70 percent of affected coastline), overwash along $479 \mathrm{~km}$ (33 percent of affected coastline) and inundation along $112 \mathrm{~km}$ (8 percent of affected coastline) (table 1). Note that the percent of coast forecast to be affected may add up to less or more than 100 percent, as the three metrics are calculated independently.

During the storm, the coastal change forecast used the best elevation data available at the time for the State of Florida, which were collected from 2009 to 2010 (fig. 7, table 1). A lidar elevation survey was collected along the Florida Atlantic coast in July 2016 but was not processed in advance of the storm. Following the storm, coastal change predictions for Matthew were re-calculated using the 2016 data. In the following sections on Florida, this information was used for analysis because it is the most accurate measure of pre-storm coastal elevations.

Table 1. Forecast prediction of the percentage of sandy coast very likely (probability $>90$ percent) to experience coastal change during Hurricane Matthew (updated 1200 Coordinated Universal Time [UTC] Friday, October 7, 2016, National Hurricane Center [NHC] Advisory 37). Florida calculations based on 2009-2010 data available during the storm.

$[\%$, percentage; S.C., South Carolina]

\begin{tabular}{lccc}
\hline Spatial coverage by region & Collision & Overwash & Inundation \\
$\%$ & $\%$ & 24 & 1 \\
\hline Florida east coast & 77 & 73 & 35 \\
Georgia & 97 & 71 & 15 \\
South Carolina & 100 & 2 & 0 \\
North Carolina (S.C. border to Cape Hatteras) & 24 & 33 & 8 \\
\hline Predicted \% of coastal change & 70 & \begin{tabular}{c}
$\%$ \\
\hline
\end{tabular}
\end{tabular}

\section{U.S. Geological Survey Coastal-Change Observations}

The following data were collected in response to Hurricane Matthew as a means to describe and characterize the post-storm state of the coast and to qualify storm effects:

- Post-Hurricane Matthew coastal oblique aerial photography_USGS Coastal and Marine Geology Program; completed October 13-15, 2016

- Rapid Response Imagery aerial photography_NOAA NOS National Geodetic Survey (NGS) Remote Sensing Division; completed October 7-16, 2016

- Post-storm airborne-lidar topographic survey-USACE JALBTCX, in cooperation with the USGS Coastal and Marine Geology Program; completed October 28-November 26, 2016

\subsection{Oblique Aerial Photography}

The USGS collected low altitude post-storm coastal oblique aerial photography of affected regions from October 13-15, 2016, from Port St. Lucie, Fla. through Kitty Hawk, N.C.; a stretch of coastline approximately $1,350 \mathrm{~km}$ long (fig. 7). Photography was captured with a Nikon D810 camera aboard a Cessna 182 aircraft at an altitude of $150 \mathrm{~m}$ and approximately $365 \mathrm{~m}$ offshore. A sample rate of one image every $2 \mathrm{~s}$ resulted in a total of 15,728 images (Morgan, 2017b). Table 2 provides details about the photographs representing the pre-storm conditions. Examples of both pre- and post-storm photographs 
obtained during these two flights are available online (https://www.usgs.gov/centers/spcmsc/science/ hurricane-matthew-storm-response). The complete library of pre- and post-Matthew photographs can be accessed at https://coastal.er.usgs.gov/hurricanes/tools/oblique.php?mission=Matthew2016.

In addition to supporting descriptions of the coastal changes that resulted from Hurricane Matthew, these data are available to emergency and coastal managers and others concerned with the storm's effect on the coast. These images may be especially useful in providing information about difficult to access locations.

\subsection{Airborne Lidar Topographic Surveys}

An airborne lidar survey to document post-storm coastal geomorphology, covering an area that stretched from Key Biscayne, Fla., northward through Virginia, began twenty days after landfall on October 28, 2016, and was completed on November 26, 2016. Because of the extensive area affected by Hurricane Matthew, the pre-storm topography was defined through the use of multiple surveys (fig. 7). The survey dates and spatial coverage for each pre-storm survey are detailed in table 3 . Examples of

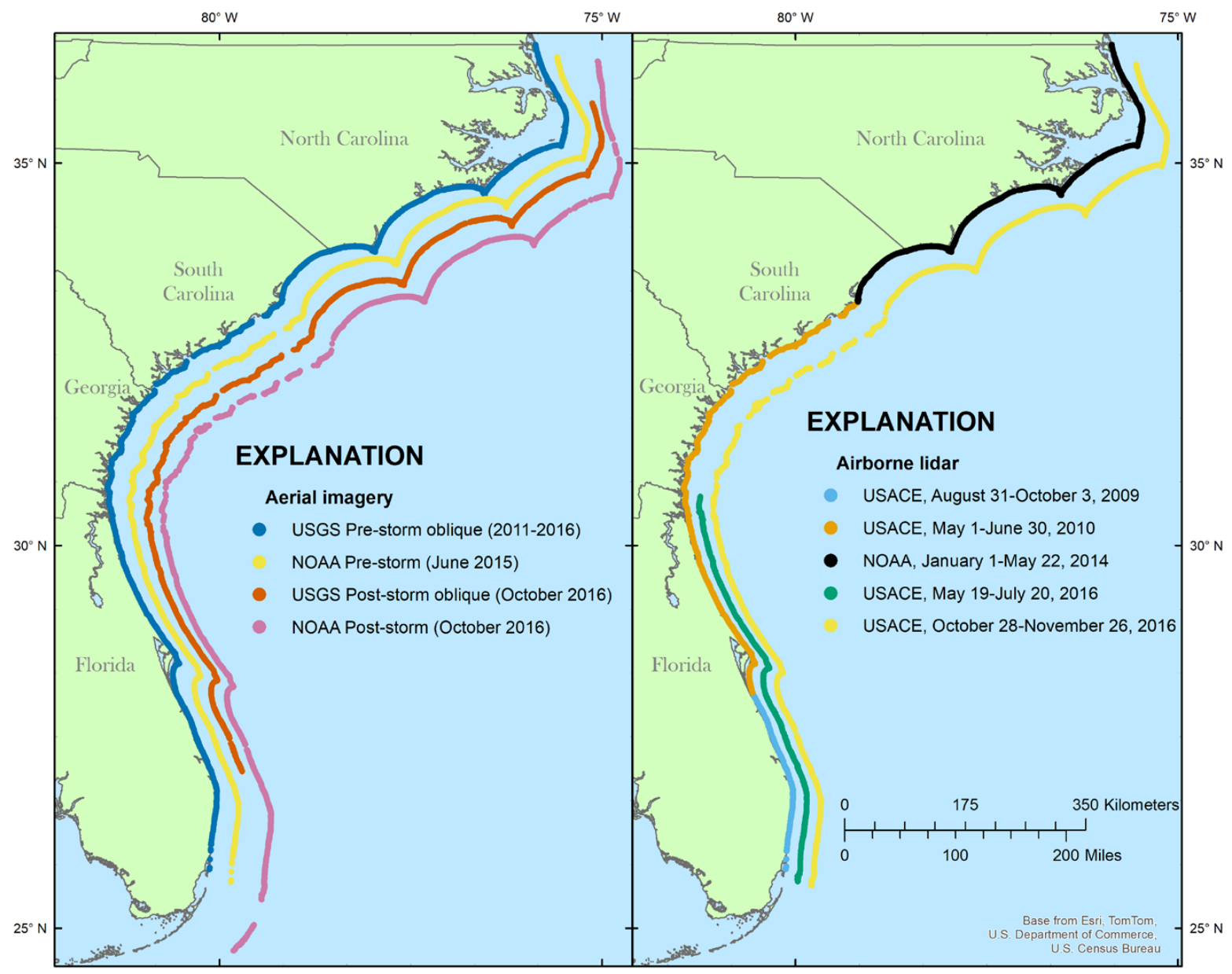

Figure 7. Map showing Hurricane Matthew pre- and post-storm aerial photography (left) and airborne lidar coverage (right), carried out by the U.S. Geological Survey (USGS), the National Oceanic and Atmospheric Administration (NOAA), and the U.S. Army Corps of Engineers (USACE). 
Table 2. Details of the pre- and post-storm photography collection used for qualitative analysis of coastal-change and quantitative visual overwash delineation.

[USGS, U.S. Geological Survey; NOAA, National Oceanic and Atmospheric Administration]

\begin{tabular}{|c|c|c|}
\hline Survey date & Spatial coverage & Agency \\
\hline August 24, 2011 & Georgia to South Carolina $^{1}$ & USGS \\
\hline September 6, 2014 & Florida $^{2}$ & USGS \\
\hline June $13-18,2015$ & Florida to North Carolina & NOAA \\
\hline February 18-19, 2016 & North Carolina ${ }^{3}$ & USGS \\
\hline October 7-16, 2016 & Key Largo, Florida to Virginia Beach, Virginia & NOAA \\
\hline October 13-15, 2016 & Port St. Lucie, Florida to Kitty Hawk, North Carolina ${ }^{4}$ & USGS \\
\hline
\end{tabular}

\footnotetext{
${ }^{1} \operatorname{Morgan}(2017 \mathrm{c})$

${ }^{2}$ Morgan (2015)

${ }^{3}$ Morgan (2017a)

${ }^{4}$ Morgan (2017b)
}

Table 3. Details of the pre- and post-storm lidar data used for quantitative coastal-change analysis. [USACE, U.S. Army Corps of Engineers; NOAA, National Oceanic and Atmospheric Administration]

\begin{tabular}{lll}
\hline \multicolumn{1}{c}{ Survey date } & Agency & \multicolumn{1}{c}{ Spatial coverage } \\
\hline August 31-October 3, 2009 & USACE & South Florida to Melbourne, Florida (used only in forecast during storm) \\
May 1-June 30, 2010 & USACE & Melbourne, Florida to Winyah Bay, South Carolina \\
January 8-May 22, 2014 & NOAA & Winyah Bay, South Carolina to North Carolina-Virginia Border \\
May 19-July 20, 2016 & USACE & Florida Atlantic coastline \\
October 28-November 26, 2016 & USACE & Key Biscayne, Florida to Virginia-Maryland Border \\
\hline
\end{tabular}

pre- and post-storm comparisons of lidar elevation are available online (https://www.usgs.gov/centers/ spcmsc/science/national-assessment-storm-induced-coastal-change-hazards) and in Section 6, Forecast Validation. The post-Hurricane Matthew lidar data were compiled to meet a vertical accuracy of 19.6 centimeters and a horizontal-position accuracy of $1 \mathrm{~m}$ with a 95-percent confidence level, as reported by the U.S. Army Corps of Engineers.

\subsection{Overwash Delineation}

The NOAA NOS NGS Remote Sensing Division collected aerial photography of the affected coastline from the Florida Keys to the Chesapeake Bay mouth in Virginia from October 7 to October 16, 2016. The USGS NACCH project analyzed this post-storm aerial photography for dune overwash and breaching along the coasts of Florida, Georgia, South Carolina, and North Carolina (fig. 8). The method involved visually inspecting pre- and post-storm imagery in the ArcGIS environment and marking the locations of observed overwash and the breaching of dunes caused by Hurricane Matthew (fig. 9; Doran and others, 2017). 


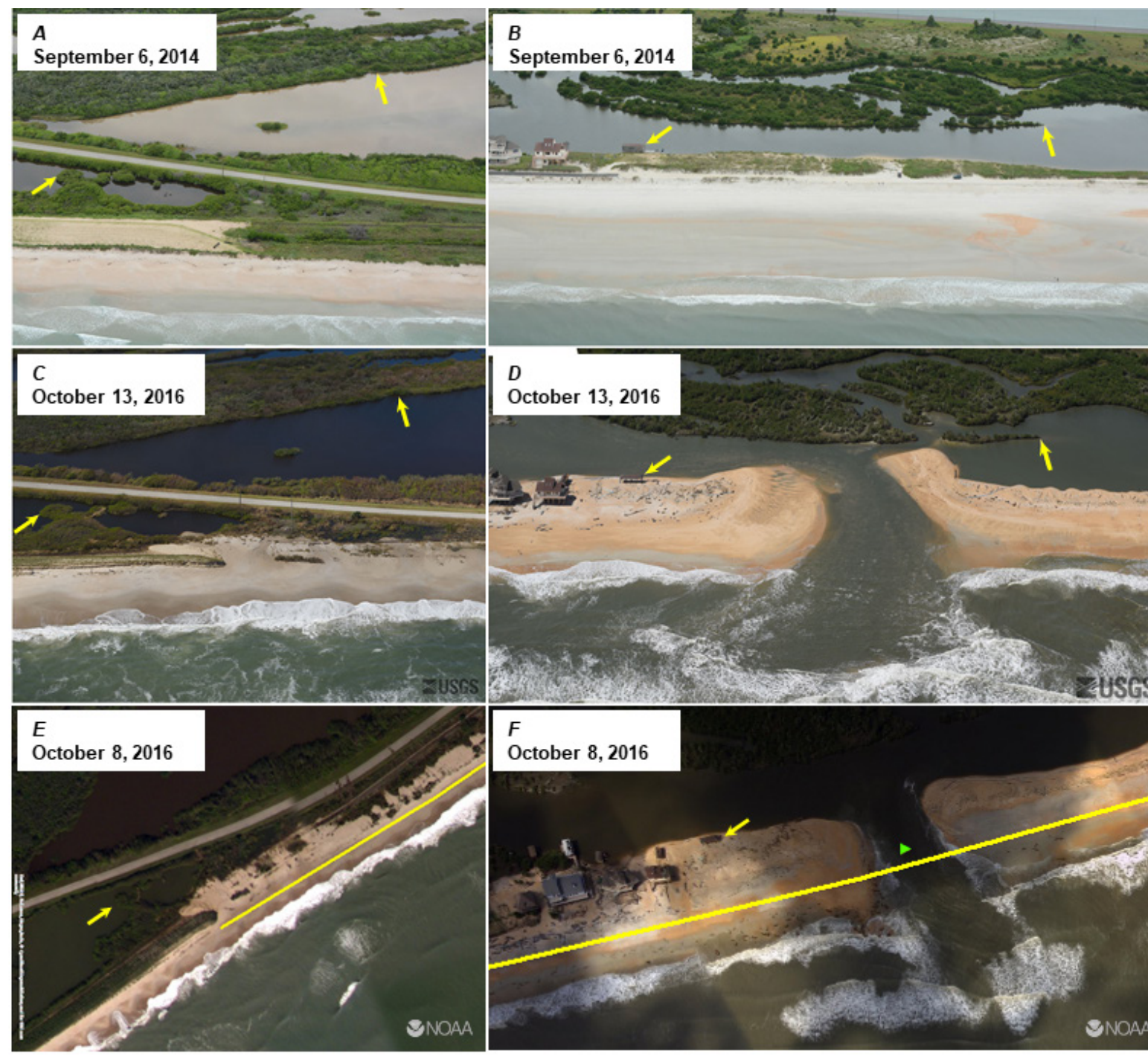

Figure 8. Aerial imagery of $(A, C, E)$ Cape Canaveral, Florida, and $(B, D, F)$ St. Augustine, Florida. Oblique aerial photographs show the coast before (top row) and after (middle row) Hurricane Matthew. Views are west across the Florida shore. Storm waves and currents eroded the beach and dunes at Kennedy Space Center creating a break in the dune and allowing sand to overwash into the backshore. A breach opened during the storm at St. Augustine due to elevated water levels and large storm waves that overwashed and flooded a low-lying section of the coast. The yellow arrows in all photographs point to the same feature in the corresponding pre- or post-storm image. Bottom row images show National Oceanic and Atmospheric Administration (NOAA) post-storm aerial imagery, with a yellow line delineating observed overwash and a green triangle denoting an observed breach.

\section{Forecast Validation}

This section contains a validation of the coastal change forecast. Locations where overwash was forecast with a probability $>90$ percent were defined as the forecast values and were compared with the observed overwash delineation (Section 5.3, Overwash Delineation; fig. 9). The quantity of observed overwash is reported in two ways. The total length of overwash is the cumulative sum of the alongshore lengths for all instances of overwash within each State. The high-resolution delineation of observed alongshore overwash extent was also used to classify 1-kilometer (km) bins alongshore, such 


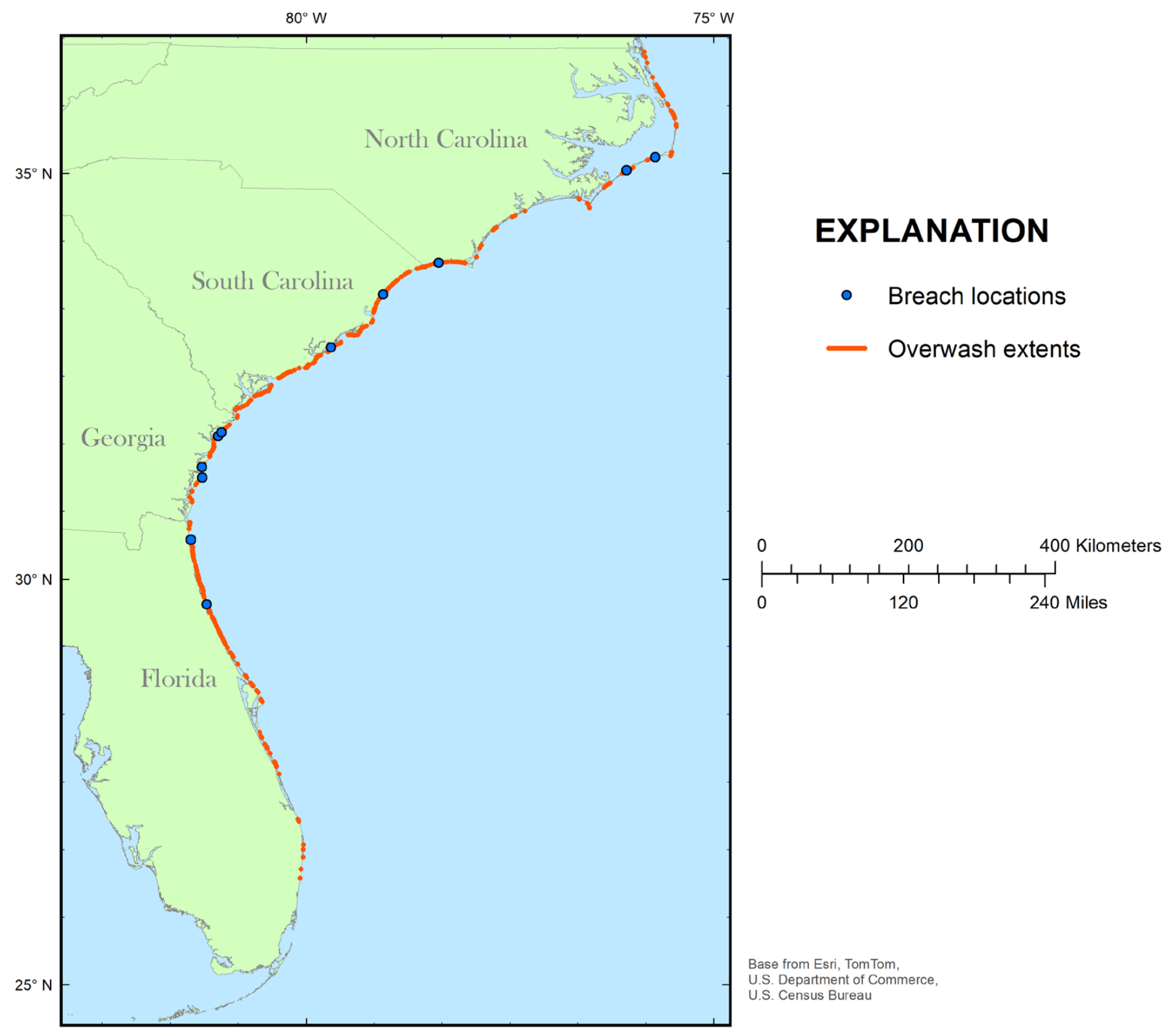

Figure 9. Map showing Hurricane Matthew overwash extent delineations and breach locations for Florida through North Carolina.

that if overwash occurred anywhere in the bin, overwash was observed for the entire bin and could be compared with the forecast values. The results of the comparison are presented in contingency tables (tables 4-7) along with the forecast biases and Brier scores. The contingency tables give the discrete joint distribution of forecasts and observations in terms of bin counts and show the number of correctly forecast bins, false negatives, and false positives. The bias is calculated by taking the number of forecast overwash events and dividing it by the number of observed overwash events. A bias greater than 1 indicates overprediction, while a bias less than 1 indicates underprediction.

The Brier score (BS) is a measure of forecast skill using the full range of forecast probabilities, where a perfect forecast equals 0 and a completely imperfect forecast equals 1 (equation 1). 


$$
B S=\frac{1}{N} \sum_{t=1}^{N}\left(f_{t}-o_{t}\right)^{2}
$$

where

$N \quad$ is the number of locations;

$f \quad$ is forecast probability; and

$o \quad$ is the observation $(1=$ overwash, $0=$ none $)$.

A Brier score of less than 0.25 is skillful, meaning better than random.

Because the storm provides the hydrodynamic forcing for the observed coastal changes and the magnitudes of erosion typically scale with distance from landfall, coastal storm effects and change are presented relative to the location of landfall, where negative values represent the distance along the shoreline to the left of landfall and positive values indicate distance, moving along the coast, to the right of landfall.

The storm effects and the pre-storm forecasts varied by State due to the changing characteristics of Hurricane Matthew as it made its way along the coast and how the storm surge and waves interacted with the varied morphology along the coastline of each State. Georgia and South Carolina were affected more heavily, and the forecasts predicted more widespread effects in those States.

\subsection{Florida}

The coastal change forecast for Florida, which was disseminated during the storm, used lidar data from 2009 and 2010. Overwash was initially forecast along 23 percent of the coast (which is 23 percent of alongshore bins). Inundation was forecast along 1 percent of the coast. The following validation uses the pre-storm 2016 data for Florida that were unavailable during the storm. By total length, approximately 11 percent of the State of Florida's Atlantic coast dunes experienced overwash based on visual comparisons of pre- and post-storm aerial imagery (fig. 9). Overwash was observed in 22 percent of alongshore bins. Overwash was forecast along 13 percent of the coast. The forecast overwash was correctly determined at 45 of 81 locations; overwash was forecast but not observed at 36 locations; and overwash was observed but not forecast at 86 locations (table 4). Overwash was underpredicted (bias $<1$ ), but the forecast was skillful ( $\mathrm{BS}=0.20$ ) due to the number of non-overwash locations correctly forecast. Breaching occurred at three locations along the Florida coast, two south of Matanzas Inlet $(\mathrm{DFL}=-440 \mathrm{~km})$ and one along Little Talbot Island $(\mathrm{DFL}=-349 \mathrm{~km})$. Inundation was forecast along $<1$ percent of the coast. Inundation was not forecast at any of the three observed-breach locations.

Table 4. Contingency table for Florida showing the number of locations where overwash was and was not predicted alongside corresponding locations where overwash was and was not observed. The bias and Brier score (equation 1) give summary statistics for the predicted and observed data. The values predicted by forecast are from the hindcast and used pre-storm data; the values observed at forecast locations are from the visual overwash delineation.

\begin{tabular}{cccccc}
\hline \multirow{2}{*}{ Florida overwash } & \multicolumn{3}{c}{ Observed at forecast locations } \\
\cline { 3 - 6 } & & Yes & No & Bias & Brier score \\
\hline $\begin{array}{l}\text { Predicted by } \\
\text { forecast }\end{array}$ & Yes & 45 & 36 & 0.62 & 0.20 \\
\hline
\end{tabular}




\subsection{Georgia}

By total length, approximately 30 percent of the State's dunes experienced overwash (fig. 9). Overwash was observed in 38 percent of alongshore bins. Overwash was forecast along 72 percent of the coast. The forecast shown in this report correctly predicted overwash at 55 of 123 locations; predicted but did not observe overwash at 68 locations; and observed but did not predict overwash at 10 locations (table 5). Breaching occurred at four locations along the Georgia coast: two at Ossabaw Island, and one each at Little St. Simons Island and Sapelo Island. Inundation was forecast along 36 percent of the coast. Along Sapelo Island and Ossabaw Island, inundation was predicted at the locations where breaches were observed. Inundation was not predicted at the observed-breach location along Little St. Simons Island.

The State of Georgia had a bias value of 1.89, showing that the forecast overpredicted locations where overwash would occur. The Brier score of 0.48 indicates that the forecast was not skillful for Georgia, as seen by the greater number of false positives than true positives.

Table 5. Contingency table for Georgia showing the number of locations where overwash was and was not predicted and corresponding locations where overwash was and was not observed. The bias and Brier score (equation 1) give summary statistics for the predicted and observed data. The values predicted by forecast are from the pre-storm forecast; the values observed at forecast locations are from the visual overwash delineation.

\begin{tabular}{cccccc}
\hline \multirow{2}{*}{ Georgia overwash } & \multicolumn{3}{c}{ Observed at forecast locations } \\
\cline { 2 - 6 } & & Yes & No & Bias & Brier score \\
\hline Predicted by & Yes & 55 & 68 & 1.89 & 0.48 \\
forecast & No & 10 & 37 & & \\
\hline
\end{tabular}

\subsection{South Carolina}

By total length, approximately 37 percent of the State's dunes experienced overwash (fig. 9). Overwash was observed in 48 percent of alongshore bins. Overwash was forecast along 71 percent of the coast. The forecast shown in this report correctly predicted overwash at 123 of 212 locations; predicted but did not observe overwash at 89 locations; and observed but did not predict overwash at 34 locations (table 6). Breaching occurred at two locations along the South Carolina coast: at Capers Island (DFL $=-23 \mathrm{~km})$ and Huntington Beach State Park in Murrells Inlet (DFL $=66 \mathrm{~km})$. Inundation was forecast along 15 percent of the coast. Inundation was not predicted at either of the two observed-breach locations.

The State of South Carolina had a bias value of 1.35, showing that the forecast overpredicted locations where overwash would occur. The Brier score of 0.41 indicates that the forecast was not skillful for South Carolina. While these scores are not the best among the four States, the dominant condition is the true positive condition, and there were few locations where false negatives occurred.

\subsection{North Carolina}

By total length, approximately 9 percent of the State's dunes experienced overwash (fig. 9). Overwash was observed in 14 percent of alongshore bins. Overwash was forecast along 2 percent of the coast. The forecast shown in this report correctly predicted overwash at six of eight locations; predicted but did not observe overwash at two locations; and observed but did not predict overwash at 52 locations (table 7). Breaching occurred at three locations along the North Carolina coast, including along Holden Beach $(\mathrm{DFL}=145 \mathrm{~km})$, Portsmouth Island $(\mathrm{DFL}=439 \mathrm{~km})$, and Hatteras Island $(\mathrm{DFL}=476 \mathrm{~km})$. Inun- 
Table 6. Contingency table for South Carolina showing the number of locations where overwash was and was not predicted and corresponding locations where overwash was and was not observed. The bias and Brier score (equation 1) give summary statistics for the predicted and observed data. The values predicted by forecast are from the pre-storm forecast; the values observed at forecast locations are from the visual overwash delineation.

\begin{tabular}{cccccc}
\hline \multicolumn{2}{l}{ South Carolina overwash } & \multicolumn{4}{c}{ Observed at forecast locations } \\
\cline { 3 - 6 } & & Yes & No & Bias & Brier score \\
\hline Predicted by & Yes & 123 & 89 & 1.35 & 0.41 \\
forecast & No & 34 & 63 & & \\
\hline
\end{tabular}

Table 7. Contingency table for North Carolina showing the number of locations where overwash was and was not predicted and corresponding locations where overwash was and was not observed. The bias and Brier score (equation 1) give summary statistics for the predicted and observed data. The values predicted by forecast are from the pre-storm forecast; the values observed at forecast locations are from the visual overwash delineation.

\begin{tabular}{cccccc}
\hline \multirow{2}{*}{ North Carolina overwash } & \multicolumn{4}{c}{ Observed at forecast locations } \\
\cline { 3 - 6 } & & Yes & No & Bias & Brier score \\
\cline { 2 - 6 } $\begin{array}{c}\text { Predicted by } \\
\text { forecast }\end{array}$ & Yes & 6 & 2 & 0.14 & 0.13 \\
\hline
\end{tabular}

dation was forecast along 0 percent of the coast (for the South Carolina border through Cape Hatteras, N.C.). Inundation was not predicted at any of the three observed-breach locations.

The State of North Carolina had a bias value of 0.14, showing that the forecast underpredicted locations where overwash would occur, as can be seen by the large number of false negatives. The Brier score of 0.13 indicates that the forecast was accurate for North Carolina, although this score is improved by the numerous locations at which overwash was neither forecast nor observed.

\section{Coastal-Change Analysis}

Hurricane Matthew affected a broad swath of the South Atlantic coast, including Florida, Georgia, South Carolina, and North Carolina. Erosion, overwash, and breaching occurred on many barrier islands, including some that are densely populated and developed. Comparisons of pre- and post-storm photography were used to identify examples of coastal change that span the range of responses to the hurricane conditions. The pre-storm photography obtainment is described in table 2. Photographs are available at https://coastal.er.usgs.gov/hurricanes/tools/oblique.php?mission=Matthew2016.

Pre- and post-storm lidar elevation surveys were compared to quantify the spatial extent and magnitude of these coastal changes. Pre-storm lidar surveys were obtained from a variety of sources (table 3). After collection, the lidar data were processed to classify data points as ground, vegetation, noise, and bathymetry. The lidar-processed ground and bathymetry data points were gridded to be consistent with previous studies (Plant and others, 2002; Doran and others, 2009). The location and elevation of the dune crest and dune toe, along with the shoreline location at the mean high water elevation were extracted from both pre- and post-storm elevation grids, consistent with previous studies (Stockdon and others, 2002; Weber and others, 2005; Doran and others, 2009).

Quantitative analyses included estimated changes in coastal metrics. The elevation grids were used to compute changes in elevation and the position of the frontal sand dune or berm system, the 
shoreline position, and the beach volume at 10-m intervals in the alongshore direction. Shoreline change (in meters) was calculated as the horizontal difference between the pre- and post-storm shoreline position. The subaerial beach volume change is defined as the change in volume between the locations of the pre-storm dune toe and shoreline. This quantity is calculated by differencing the pre- and post-storm elevation grids and integrating the differenced values in the cross-shore direction, yielding the volume of change (in cubic meters) per meter alongshore of coastline. This method eliminates complications that result from structures and vegetation, which are often located landward of the dune base. The results of the coastal change analysis are presented in separate subsections, including the four coastal States within the storm response region covered by this report.

\subsection{Florida}

Pre-storm beach and dune elevation data were obtained in summer 2016, a few months before the storm. When compared with post-storm elevations, for the entire State of Florida, the mean dune elevation change was a decrease of $0.2 \mathrm{~m}$, the mean shoreline change was $1.7 \mathrm{~m}$ landward, and the mean beach volume change was a decrease of 4.3 cubic meters per meter $\left(\mathrm{m}^{3} / \mathrm{m}\right)$ (fig. 10). The most affected region for dune height change was from Beverly Beach $(\mathrm{DFL}=-460 \mathrm{~km})$ north to Amelia Island $(\mathrm{DFL}=-340 \mathrm{~km})$, while few dunes in southern Florida were markedly affected (figs. 11-14). There was no strong, consistent trend in shoreline change or beach volume change. Two areas were affected in terms of beach volume: an approximately $20-\mathrm{km}$ area centered near Daytona Beach (DFL $=-497 \mathrm{~km}$ ), which exhibited $20-40 \mathrm{~m}^{3} / \mathrm{m}$ of beach volume loss, and a small area south of St. Augustine $(\mathrm{DFL}=-415 \mathrm{~km})$, which showed signs of erosion equaling roughly $40-60 \mathrm{~m}^{3} / \mathrm{m}$ (fig. 12).

In Flagler Beach, waves and surge eroded dunes with pre-existing coastal armoring and undercut a road $(\mathrm{DFL}=-466 \mathrm{~km})$. Several houses sit among the dunes in Vilano Beach; the dune in front of these houses was completely eroded, and the building foundations were exposed, although the buildings remained standing after the storm $(\mathrm{DFL}=-408 \mathrm{~km})$. Dune erosion and landward migration of the shoreline at this and other locations left many houses more vulnerable to future storms.

Approximately 11 percent of the State's dunes experienced overwash based on visual comparisons of pre- and post-storm aerial imagery (fig. 9), resulting in the deposition of sand landward and an overall flattening of the beach topography. For example, overwash of the dunes at Vilano Beach, north of St. Augustine, Fla., resulted in the transport of large volumes of sand inland from the beach system, severe decreases of dune height (fig. 11), and significant property damage. Breaching occurred at several locations along the Florida coast, most notably along the barrier island south of Matanzas Inlet $(\mathrm{DFL}=-440 \mathrm{~km})$. Waves and surge cut a nearly 70-m wide breach through the narrow island, based on the NOAA aerial imagery from October 8, 2016. The breach was nearly 160-m wide in November 2016 (Summer Haven, St. Johns County, Fla.) and was closed in December by the Florida Department of Environmental Protection (Hurricane Damage Assessment Report for 2016, [2017]) and Taylor Engineering. A second, smaller breach, north of the larger breach, cut through the dune and nearly through the entire island. A third breach also occurred along Little Talbot Island, at the spit on the northern end of the island. 

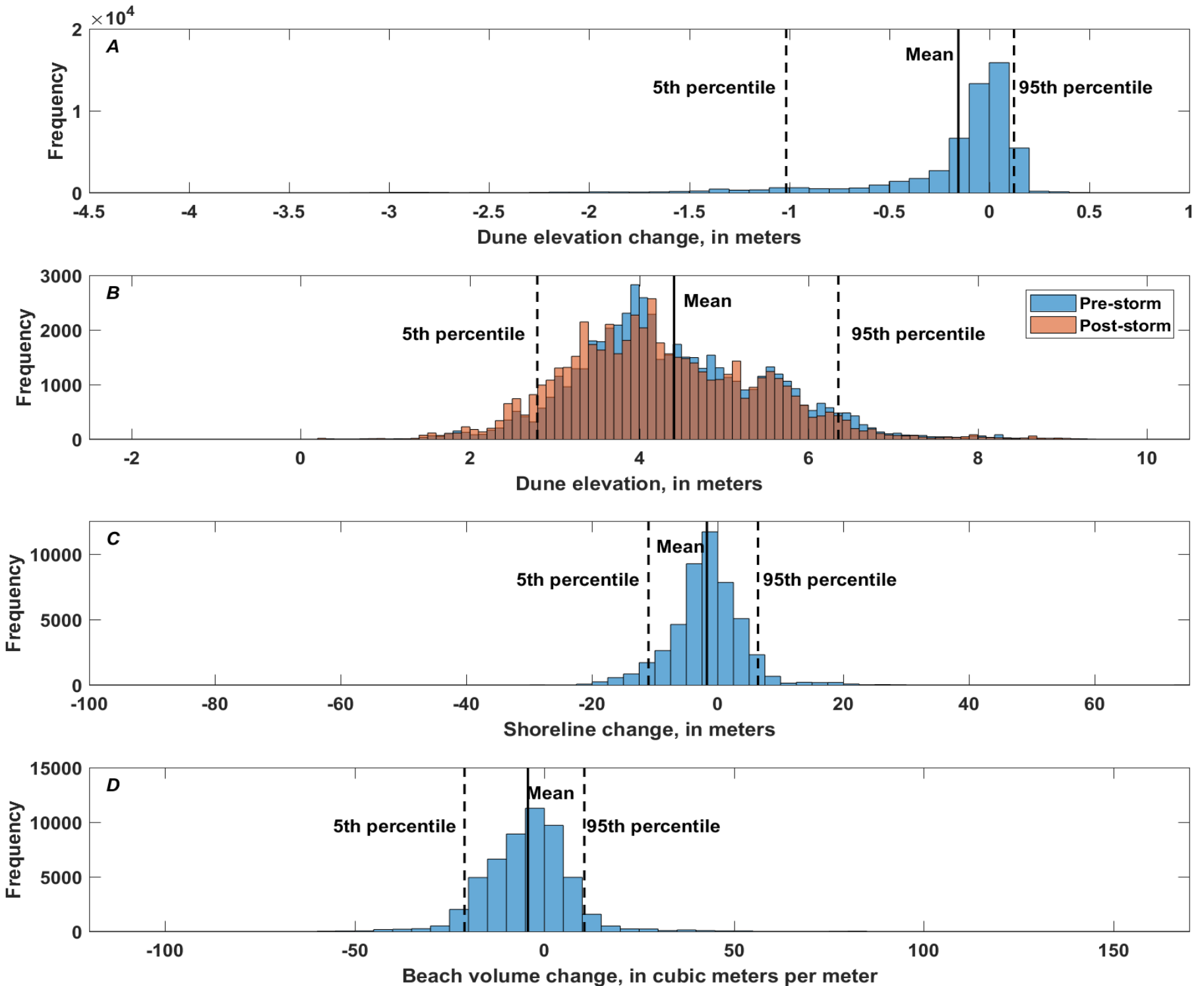

Figure 10. Combination histograms showing Hurricane Matthew $(A)$ dune elevation change, $(B)$ pre- and post-storm dune elevation (darker color indicates overlap of the two distributions), (C) shoreline change, and (D) beach volume change between May 2016 and November 2016 for the Florida coast. 
Dune elevation change
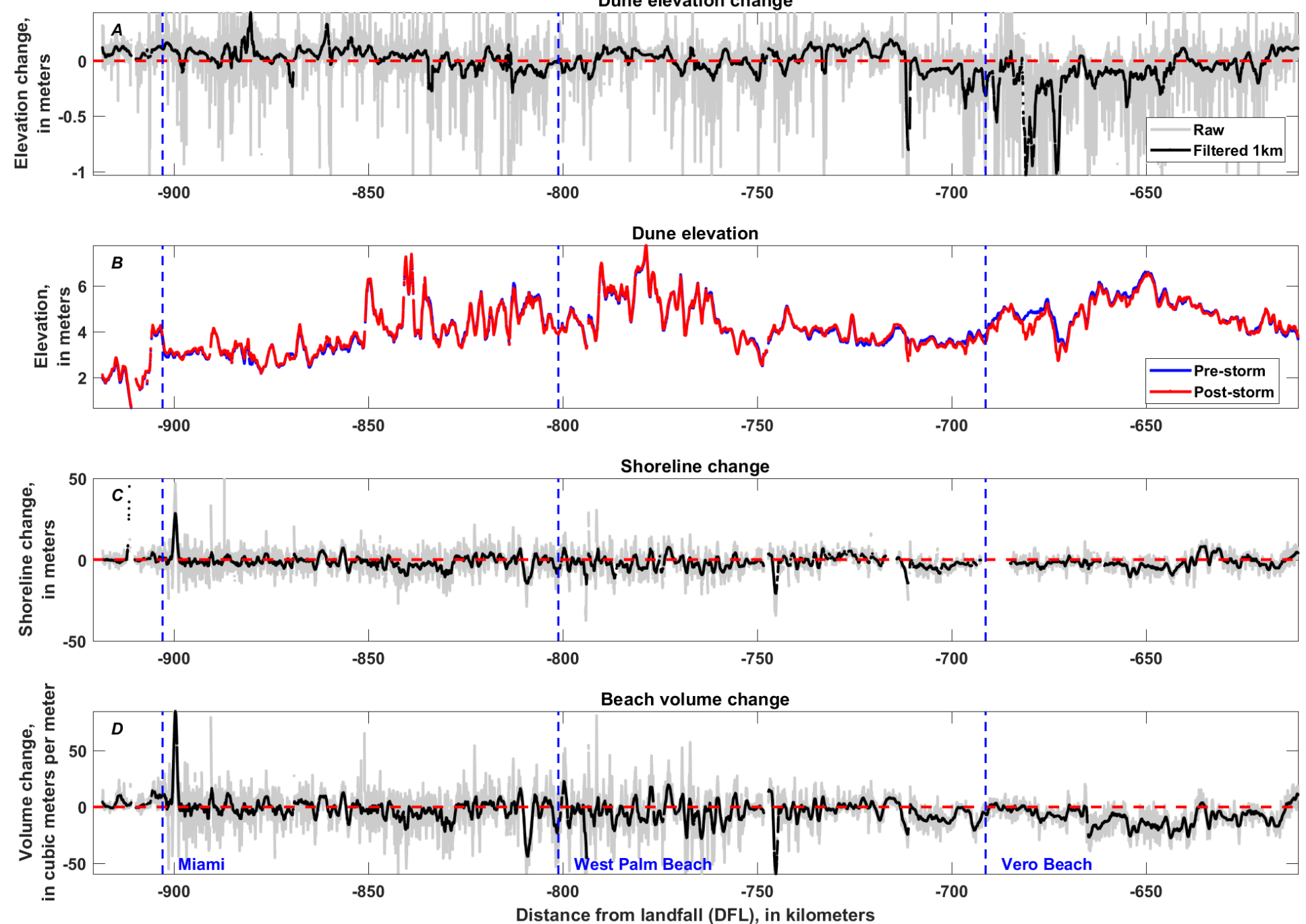

Figure 11. Combination graphs showing Hurricane Matthew $(A)$ dune elevation change, $(B)$ pre- and post-storm dune elevation, $(C)$ shoreline change, and $(D)$ beach volume change between May 2016 and November 2016 for the southern portion of the Florida Atlantic coast. The dashed blue lines indicate the cities of Miami, West Palm Beach and Vero Beach. The dashed red line denotes zero change in $A, C$, and $D$. 
Dune elevation change
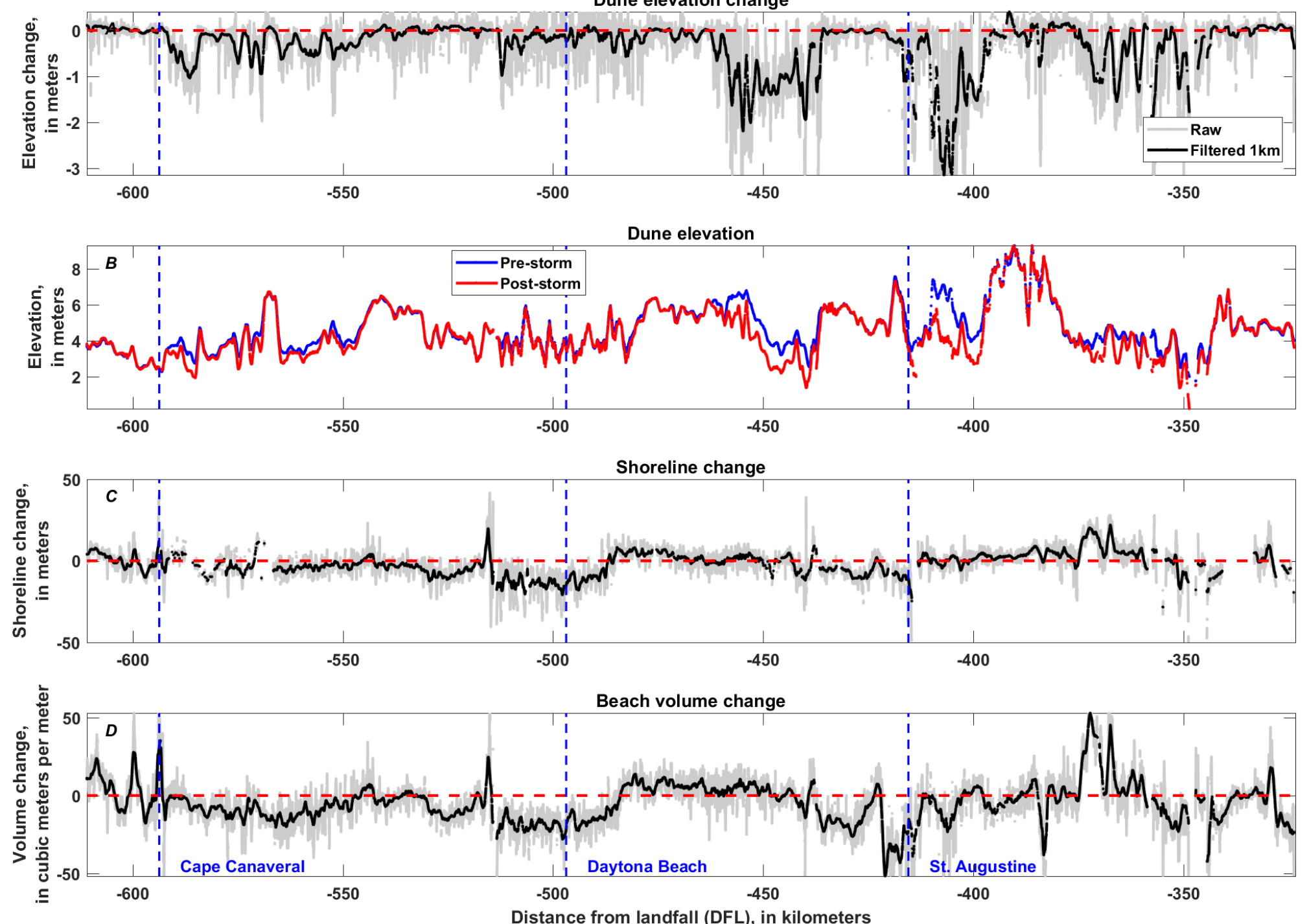

Figure 12. Combination graphs showing Hurricane Matthew $(A)$ dune elevation change, $(B)$ pre- and post-storm dune elevation $(C)$, shoreline change, and $(D)$ beach volume change between May 2016 and November 2016 for the northern portion of the Florida Atlantic coast. The dashed blue lines indicate the cities of Cape Canaveral, Daytona Beach and St. Augustine. The dashed red line denotes zero change in $A, C$, and $D$. 


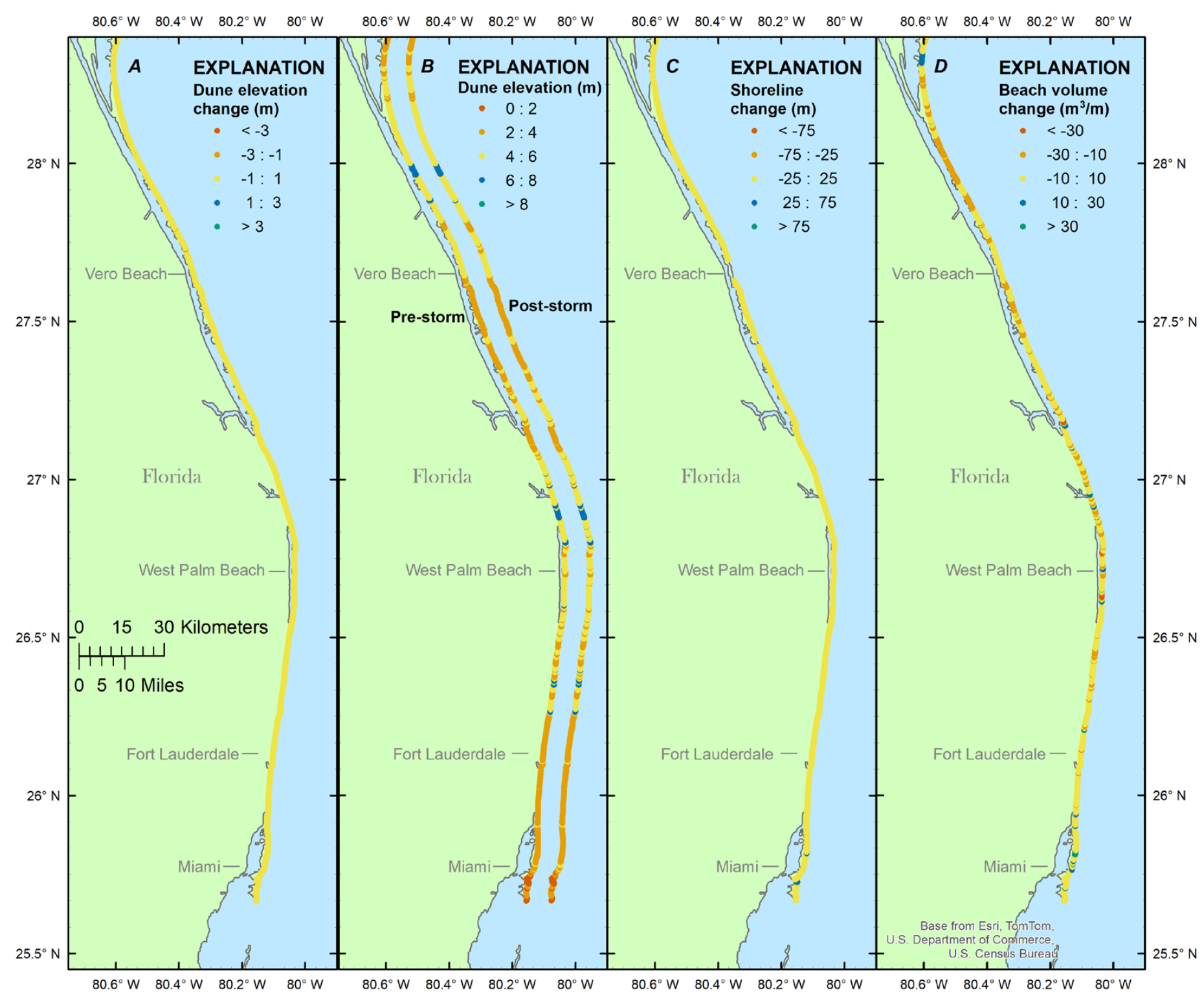

Figure 13. Maps showing Hurricane Matthew $(A)$ dune elevation change, $(B)$ pre- and post-storm dune elevation, $(C)$ shoreline change, and $(D)$ beach volume change between May 2016 and November 2016 for the southern portion of the Florida Atlantic coast. 


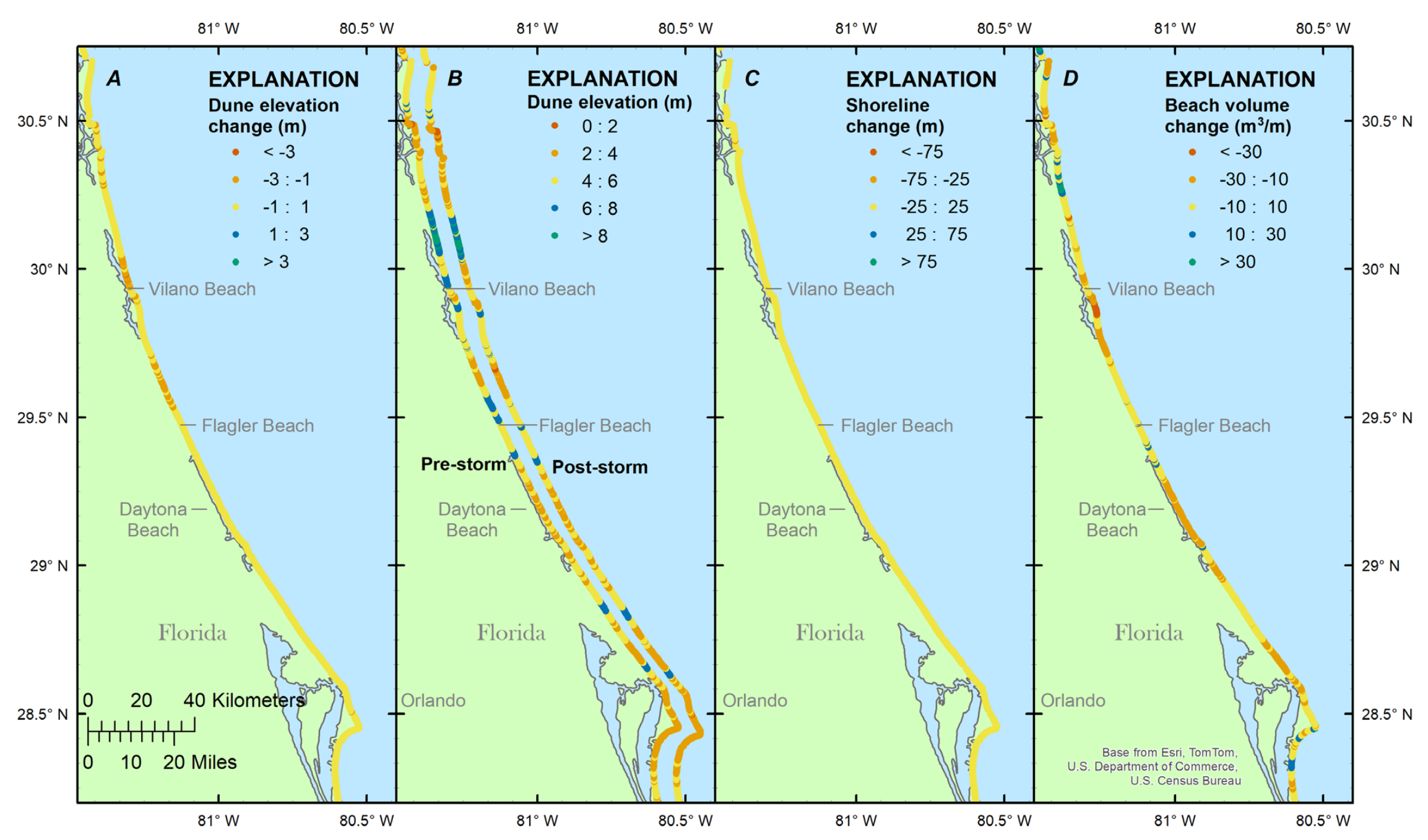

Figure 14. Maps showing Hurricane Matthew $(A)$ dune elevation change, $(B)$ pre- and post-storm dune elevation, $(C)$, shoreline change, and $(D)$ beach volume change between May 2016 and November 2016 for the northern portion of the Florida Atlantic coast. 


\subsection{Georgia}

The most recent pre-storm lidar elevation data available for Georgia were collected in May 2010. Most of the Georgia coast experienced a decrease in dune elevation due to Hurricane Matthew. For the entire State of Georgia, the mean dune elevation change was a decrease of $0.4 \mathrm{~m}$, the mean shoreline change was $1.9 \mathrm{~m}$ landward, and the mean beach volume change was an increase of $15.1 \mathrm{~m}^{3} / \mathrm{m}$ (fig. 15). Approximately 9 percent of the coast saw a dune elevation decrease of $2 \mathrm{~m}$ or more, with a maximum loss of nearly $7 \mathrm{~m}$. While some locations saw no shoreline change, there were instances of both large positive and negative changes in shoreline position (figs. 16, 17).

Because the pre-storm lidar data predate the storm by 6 years, it is likely that some of the shoreline and volume change observed between the pre- and post-storm lidar surveys of Georgia's extensive barrier island system reflect the ongoing evolution of the islands, such as in adjacent locations that see opposing changes in shoreline and beach volume, as is the case near DFL $=-265 \mathrm{~km}, \mathrm{DFL}=-238 \mathrm{~km}$, and DFL $=-208 \mathrm{~km}$.

Approximately 30 percent of the State's dunes experienced overwash (fig. 9), resulting in the deposition of sand landward and an overall flattening of the beach topography. Breaching occurred at several locations along the Georgia coast: at Little St. Simons Island, Sapelo Island, and two locations along Ossabaw Island. All four breaches involved low and narrow dunes in uninhabited areas; in the case of Ossabaw Island, the southern breach connected the ocean to a tidal channel, and the northern breach connected the ocean to a pond within the dune field. 

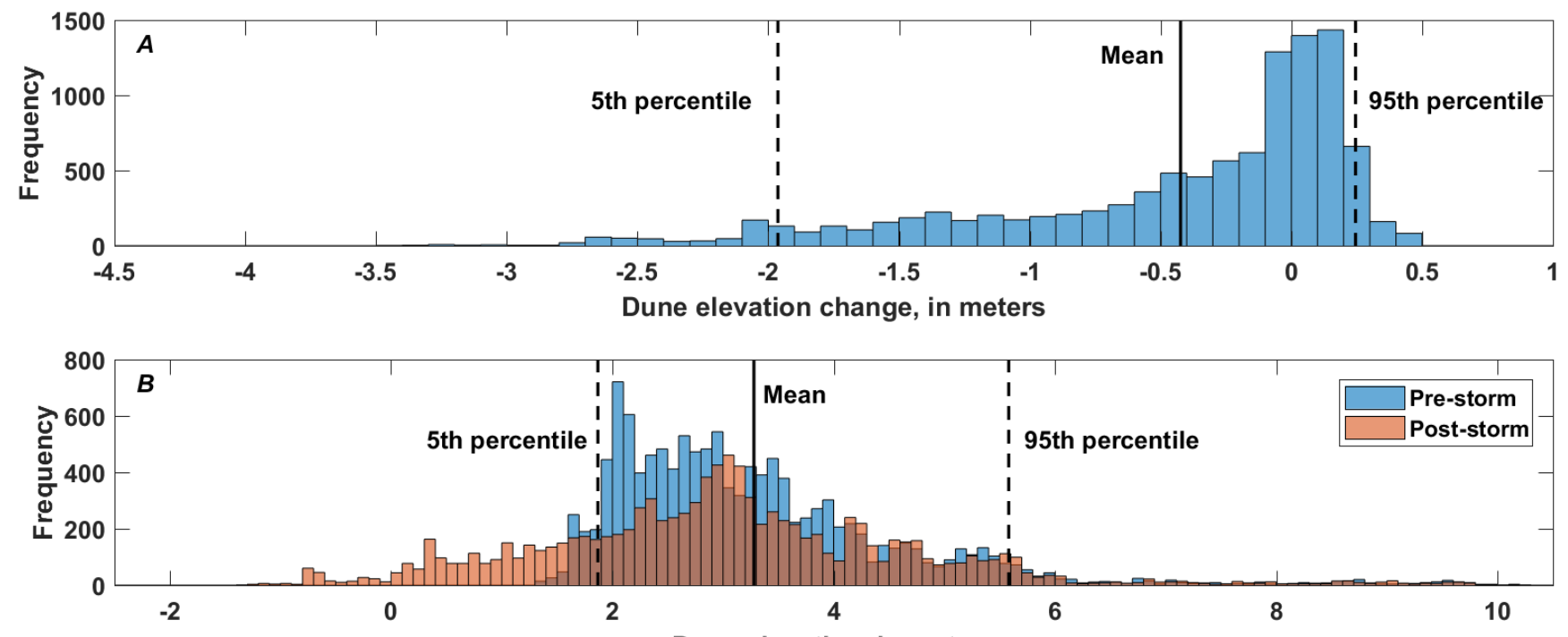

Dune elevation, in meters
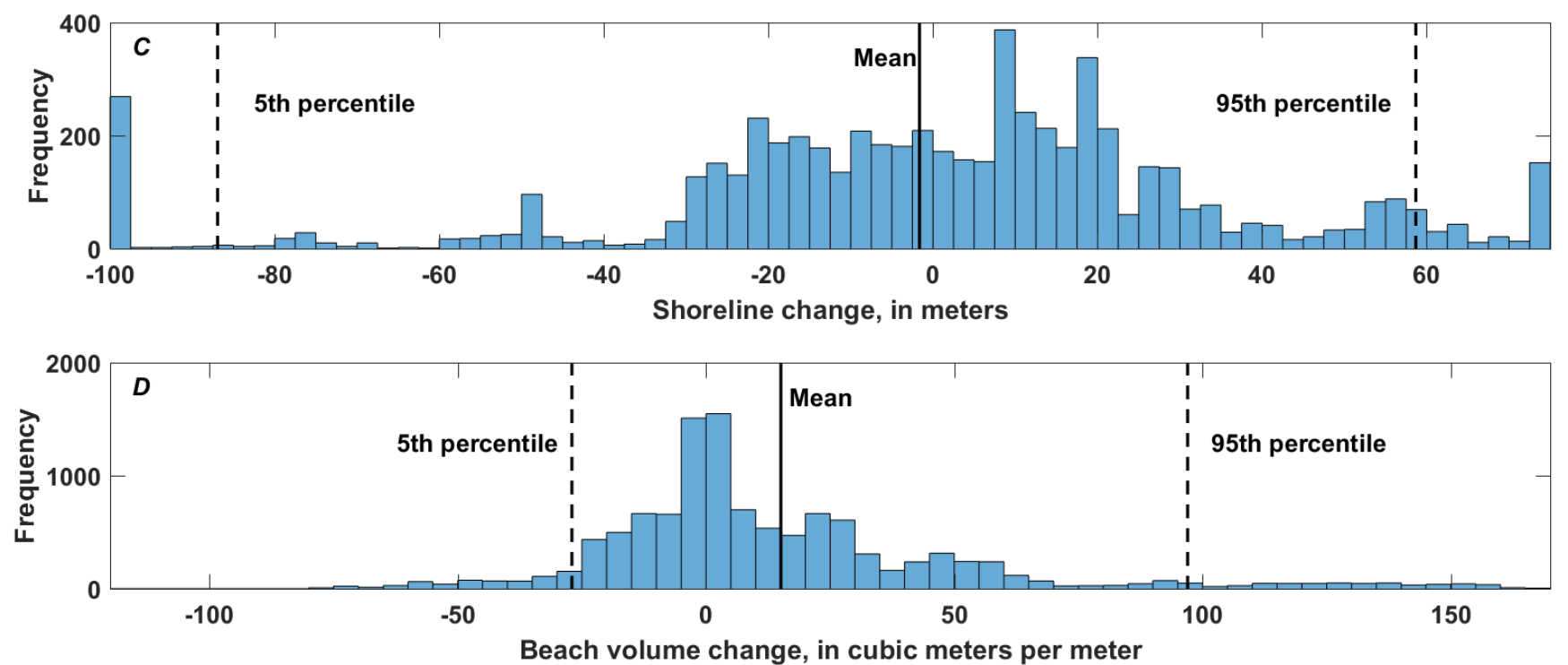

Figure 15. Combination histograms showing Hurricane Matthew $(A)$ dune elevation change, $(B)$ pre- and post-storm dune elevation (darker color indicates overlap of the two distributions), (C) shoreline change, and (D) beach volume change between May 2010 and November 2016 for the Georgia coast. 
Dune elevation change

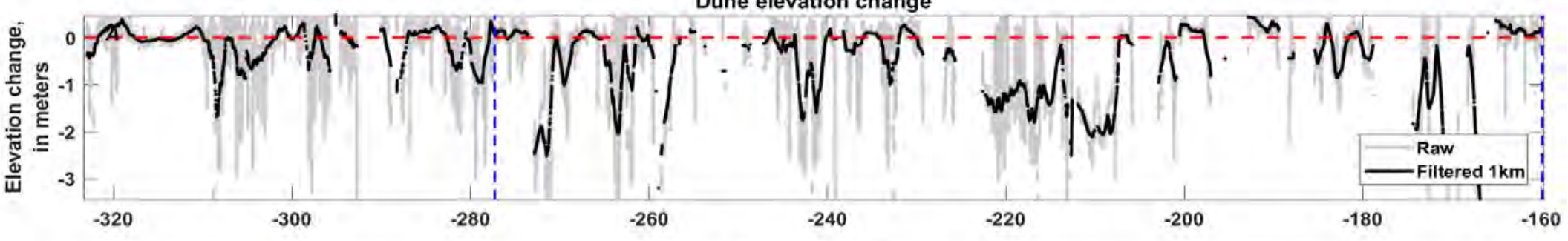

Dune elevation

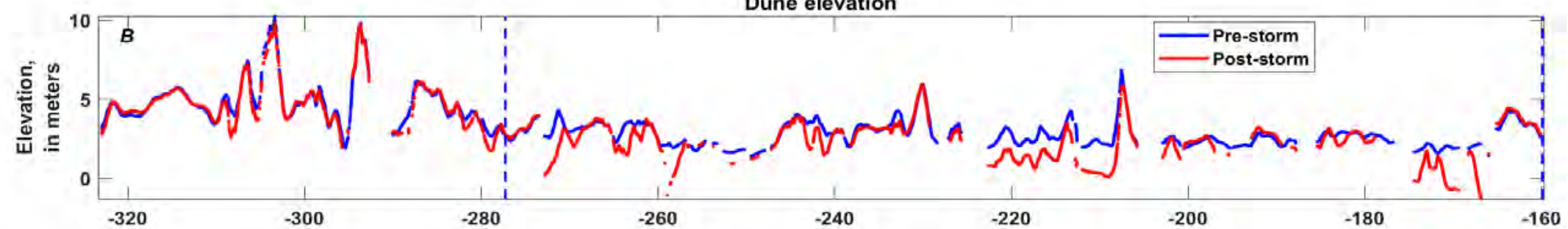

Shoreline change
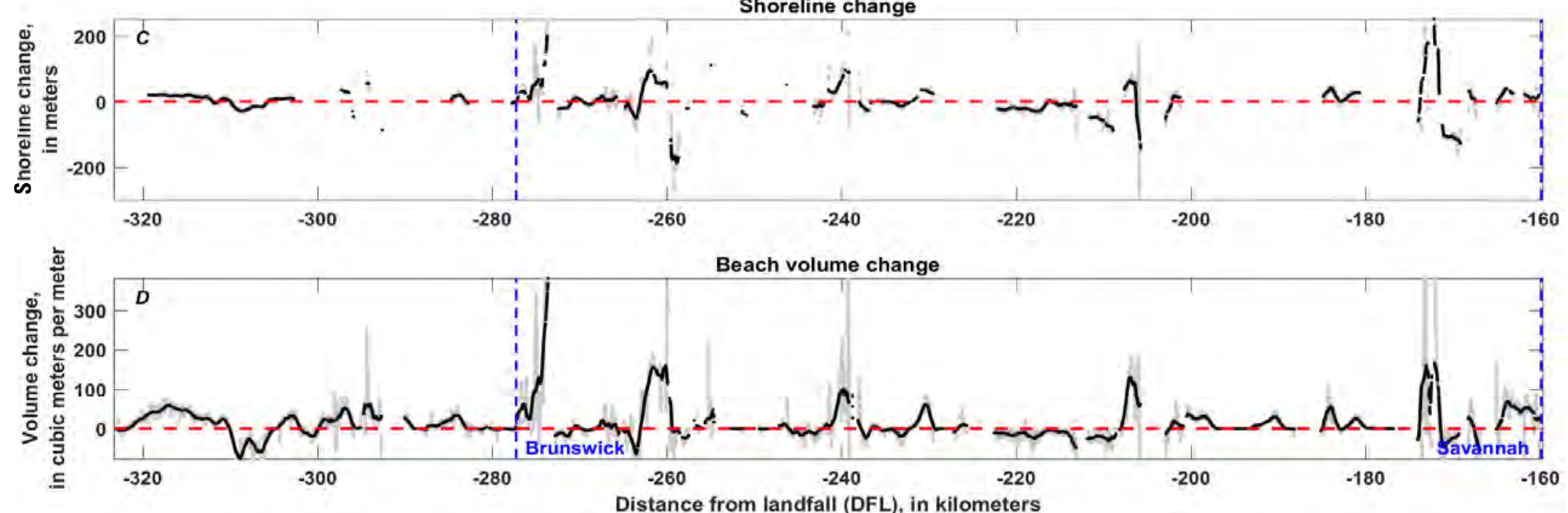

Figure 16. Combination graphs showing Hurricane Matthew $(A)$ dune elevation change, $(B)$ pre- and post-storm dune elevation, $(C)$ shoreline change, and $(D)$, and beach volume change between May 2010 and November 2016 for the Georgia coast. The dashed blue lines indicate the cities of Brunswick and Savannah. The dashed red line denotes zero change in $A, C$, and $D$. 


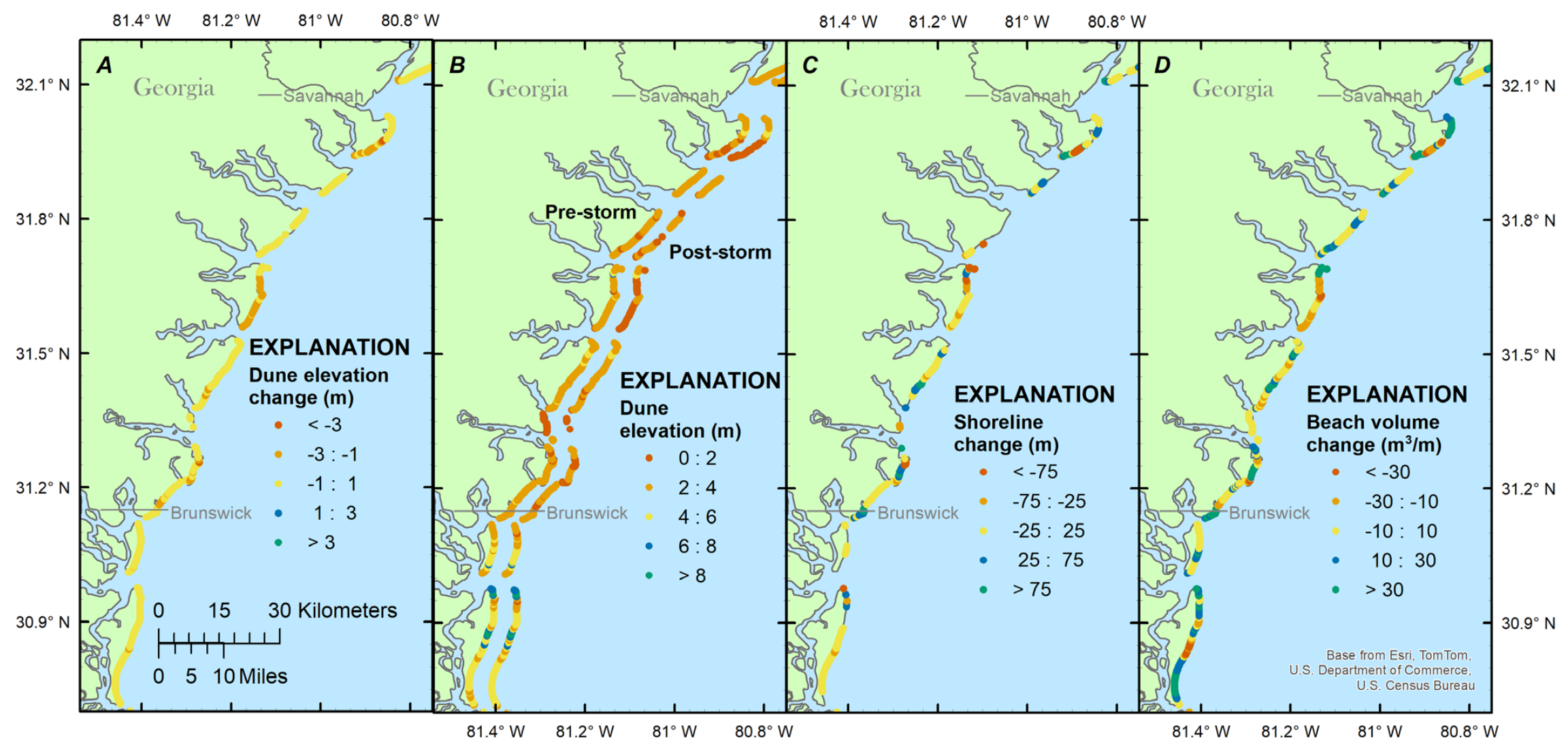

Figure 17. Maps showing Hurricane Matthew $(A)$ dune elevation change, $(B)$ pre- and post-storm dune elevation, $(C)$ shoreline change, and $(D)$ beach volume change between May 2010 and November 2016 for the Georgia coast. 


\subsection{South Carolina}

Destructive waves and storm surge associated with Hurricane Matthew severely eroded the beach and dune systems along the South Carolina coastline. Many locations along the South Carolina coast experienced severe dune erosion of greater than 1-m vertical loss (figs. 18, 19). For the entire State of South Carolina, the mean dune elevation change was a decrease of $0.5 \mathrm{~m}$, the mean shoreline change was $6.0 \mathrm{~m}$ landward, and the mean beach volume change was an increase of $7.2 \mathrm{~m}^{3} / \mathrm{m}$ (fig. 18). Approximately 6 percent of the coast saw a dune elevation decrease of $2 \mathrm{~m}$ or more, with a maximum loss of nearly $6 \mathrm{~m}$. There were many areas where a seaward increase in the shoreline position or an increase in beach volume were observed. These changes could have been caused by the transport of sand from the dune to the beach or by alongshore transport, thereby increasing the overall width and volume of the beach.

One interesting area of note is Myrtle Beach $(\mathrm{DFL}=92 \mathrm{~km})$ - while dune erosion occurred, there was a relatively small change in the shoreline position, maximum landward movement on the order of 10-15 m, and relatively little net beach-volume change (figs. 19, 20). Of interest is the fact that the effects were not more severe, considering that the eye of the storm passed almost directly over Myrtle Beach. This area experienced onshore hurricane-force winds (fig. 2), and the buoy offshore of Charleston, S.C. ( 160 km south of Myrtle Beach) recorded the largest waves at nearly $8 \mathrm{~m}$ (fig. 3). The post-storm lidar survey did not start until October 28, which was 20 days after the storm made landfall, and did not conclude until the end of November. Because of this, the minimal effects seen in the data could be indicative of beach recovery in the time between the arrival of the storm and the time data were acquired.

Approximately 37 percent of the State's dunes experienced overwash (fig. 9), resulting in the deposition of sand landward and an overall flattening of the beach topography. For example, overwash of the dunes at Edisto Beach $(\mathrm{DFL}=-100 \mathrm{~km})$ resulted in the transport of large volumes of sand inland from the beach system, severe decreases of dune height (figs. 18, 19), and significant property damage. Breaching occurred at two locations along the South Carolina coast: at Capers Island $(\mathrm{DFL}=-23 \mathrm{~km})$ and Huntington Beach State Park in Murrells Inlet (DFL $=66 \mathrm{~km})$. In both cases, waves and surge breached low dunes on narrow sections of barrier islands that appear susceptible to breaching during storms; neither occurrence affected infrastructure. 

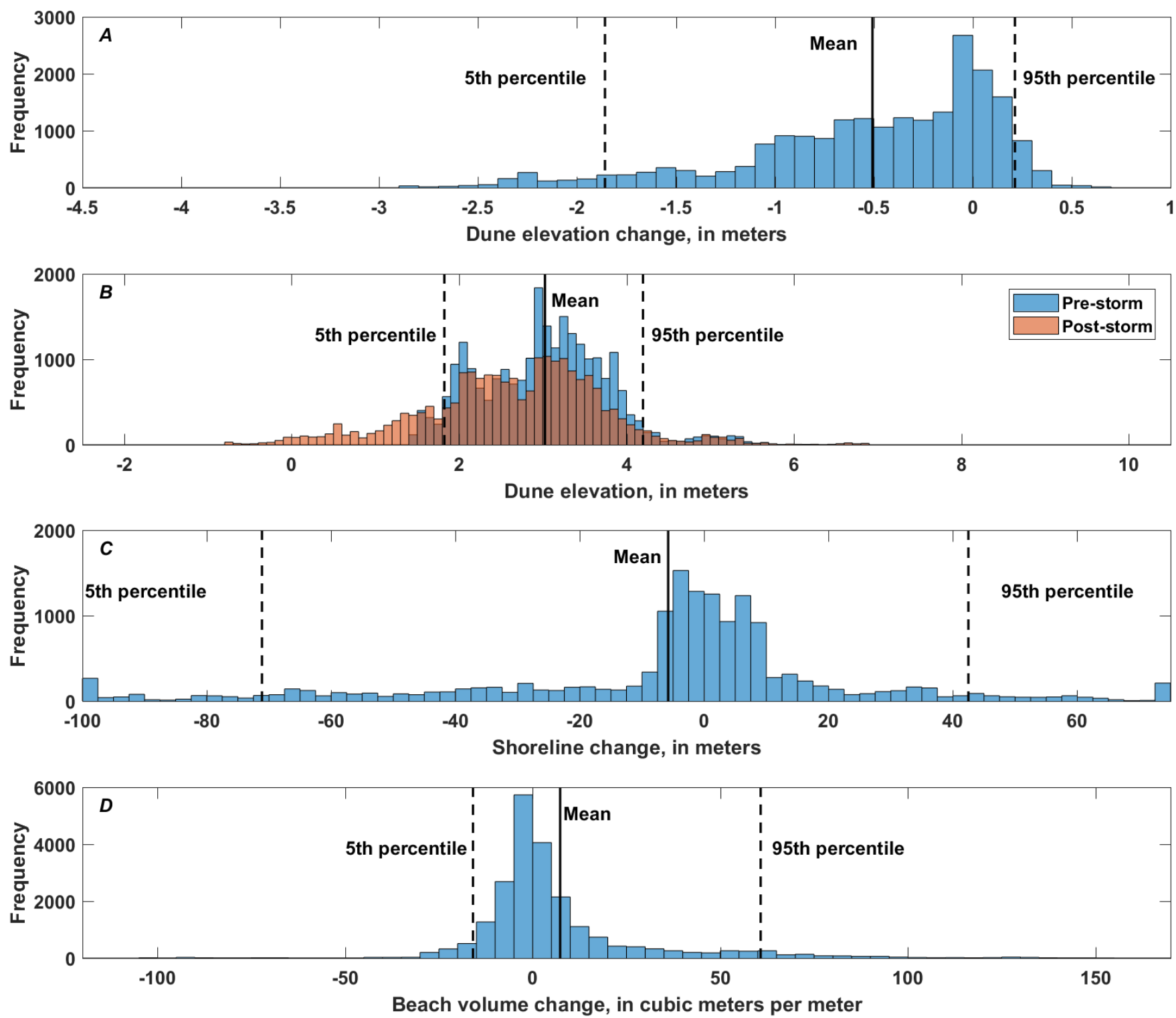

Figure 18. Combination histograms showing Hurricane Matthew $(A)$ dune elevation change, $(B)$ pre- and post-storm dune elevation (darker color indicates overlap of the two distributions), $(C)$, shoreline change, and $(D)$ beach volume change between May 2010 and November 2016 for the South Carolina coast. 

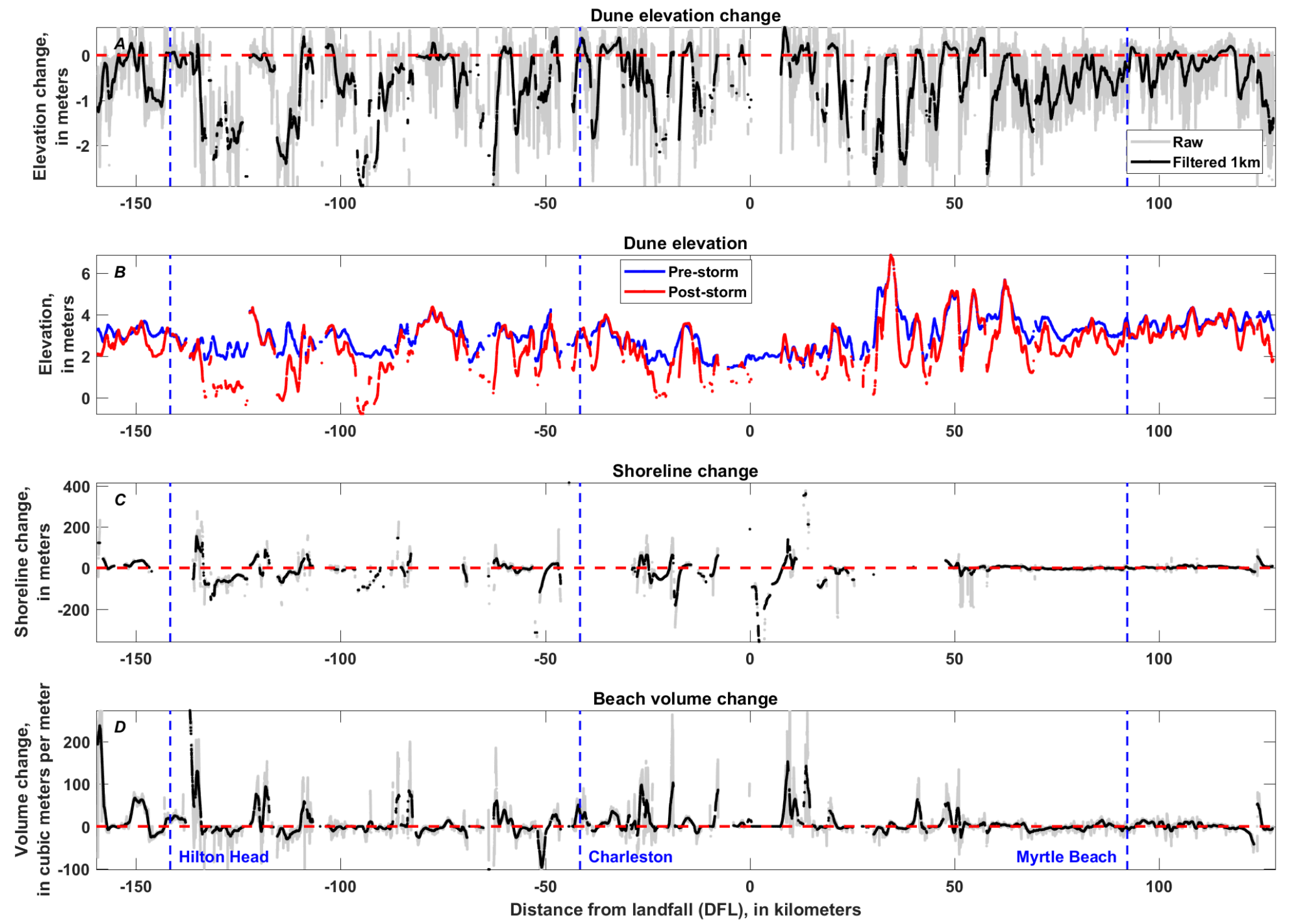

Figure 19. Combination graphs showing Hurricane Matthew $(A)$ dune elevation change, $(B)$ pre- and post-storm dune elevation, $(C)$ shoreline change, and $(D)$ beach volume change between May 2010 and November 2016 for the South Carolina coast. The dashed blue lines indicate the cities of Hilton Head, Charleston, and Myrtle Beach. The dashed red line denotes zero change in $A, C$, and $D$. 


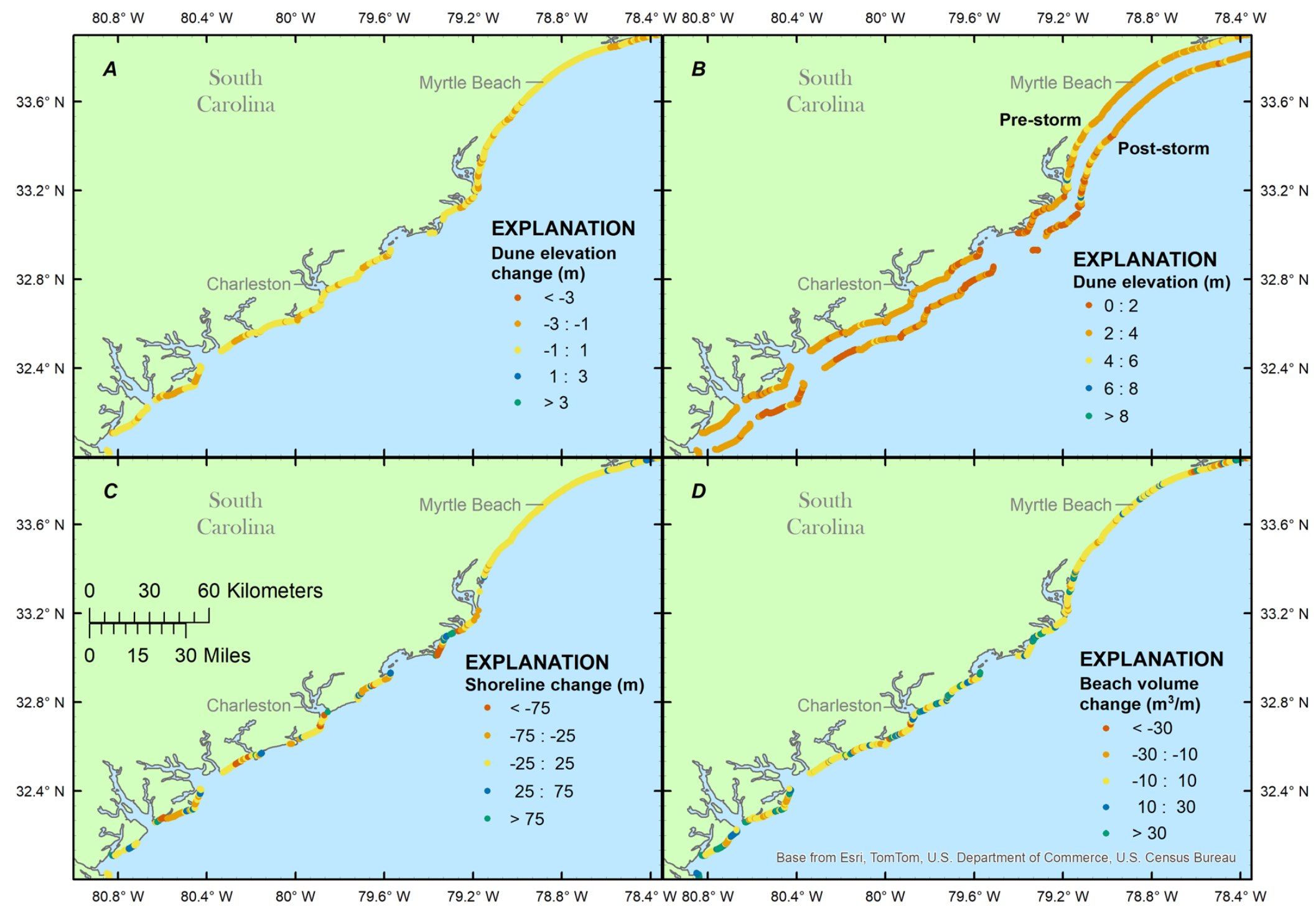

Figure 20. Maps showing Hurricane Matthew $(A)$ dune elevation change, $(B)$ pre- and post-storm dune elevation, $(C)$ shoreline change, and $(D)$ beach volume change between May 2010 and November 2016 for the South Carolina coast. 


\subsection{North Carolina}

Hurricane Matthew caused dune erosion and large volumes of sand transport along the beaches in North Carolina. For the entire State of North Carolina, the mean dune elevation change was a decrease of $0.6 \mathrm{~m}$, the mean shoreline change was $8.8-\mathrm{m}$ seaward, and the mean beach volume change was an increase of $9.9 \mathrm{~m}^{3} / \mathrm{m}$ (fig. 21). Approximately 11 percent of the coast saw a dune elevation decrease of $2 \mathrm{~m}$ or more, with a maximum loss of $7.5 \mathrm{~m}$ (figs. 21, 22). An area of positive shoreline change is present from Surf City to Browns Island (DFL $=260 \mathrm{~km}$ to DFL $=300 \mathrm{~km}$ ), where there was widespread erosion of the dunes (figs. 22, 23). Interestingly, this seaward movement in the shoreline position resulted in little increase in beach volume. The widened beach was flatter in most locations with a minimal increase in beach volume.

Along North Topsail Beach, protective dunes were eroded and overwashed (DFL $=279 \mathrm{~km})$. Near Camp Lejeune, waves and surge overwashed the dunes and transported sand into the marsh $(\mathrm{DFL}=289 \mathrm{~km})$. In Kitty Hawk, even though the storm was weakening and only bringing tropical storm force winds, dunes were still hard hit by waves and surge, and a section of coastal roadway was destroyed $(\mathrm{DFL}=593 \mathrm{~km})$.

Approximately 9 percent of the State's dunes experienced overwash (fig. 9), resulting in the deposition of sand landward and an overall flattening of the beach topography. For example, overwash of the dunes at Kitty Hawk, N.C., resulted in the transport of large volumes of sand inland from the beach system, severe decreases of dune height (fig. 22), and damage to infrastructure and property. Breaching occurred at several locations along the North Carolina coast, including along Holden Beach $(\mathrm{DFL}=145 \mathrm{~km})$, Portsmouth Island $(\mathrm{DFL}=439 \mathrm{~km})$ and Hatteras Island $(\mathrm{DFL}=476 \mathrm{~km})$. At Holden Beach, the dunes along the southern end of the island were only breached through to a dune pond and did not affect any infrastructure in that location. At Portsmouth and Hatteras Islands, Hurricane Matthew breached areas of low elevation that may have been breached in the past to connect the back bay with the ocean. Infrastructure was not affected at either location. 

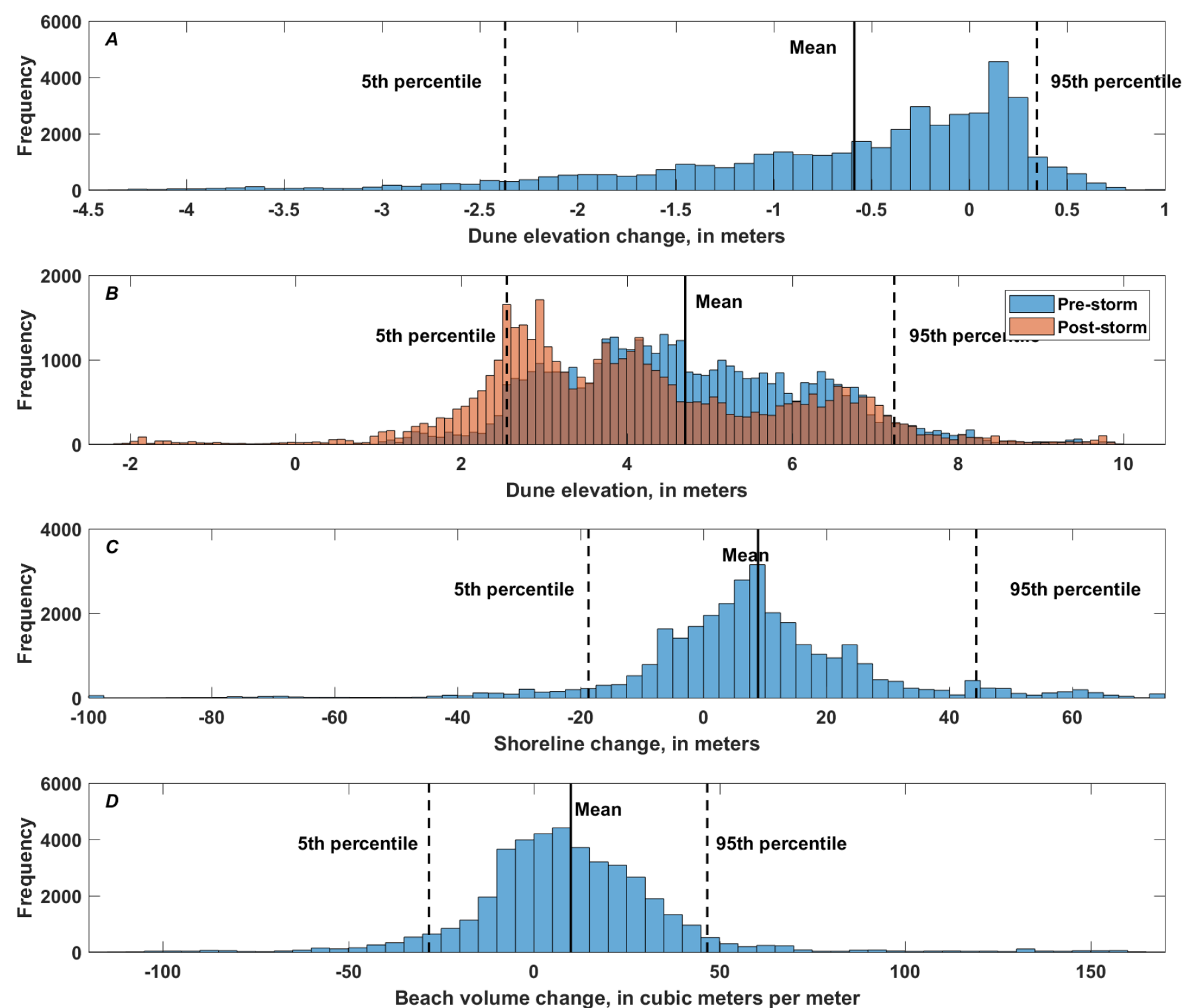

Figure 21. Combination histograms showing Hurricane Matthew $(A)$ dune elevation change, $(B)$ pre- and post-storm dune elevation (darker color indicates overlap of the two distributions), $(C)$ shoreline change, and $(D)$ beach volume change between January 2014 and November 2016 for the North Carolina coast. 
Dune elevation change
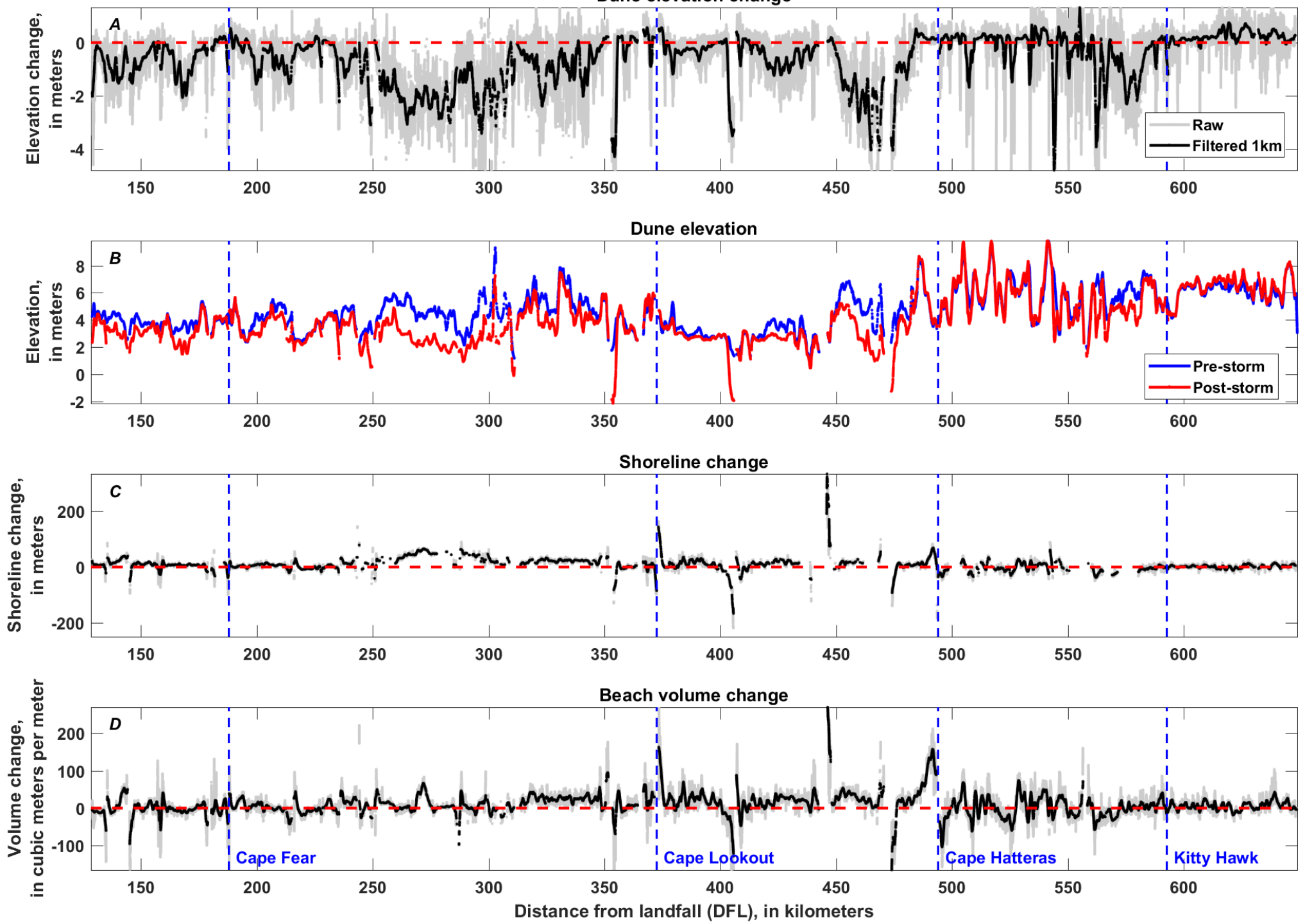

Figure 22. Combination graphs showing Hurricane Matthew $(A)$ dune elevation change, $(B)$ pre- and post-storm dune elevation, $(C)$ shoreline change, and $(D)$ beach volume change between January 2014 and November 2016 for the North Carolina coast. The dashed blue lines indicate the center of Cape Fear, Cape Lookout, Cape Hatteras and the town of Kitty Hawk. The dashed red line denotes zero change in $A, C$, and $D$. 


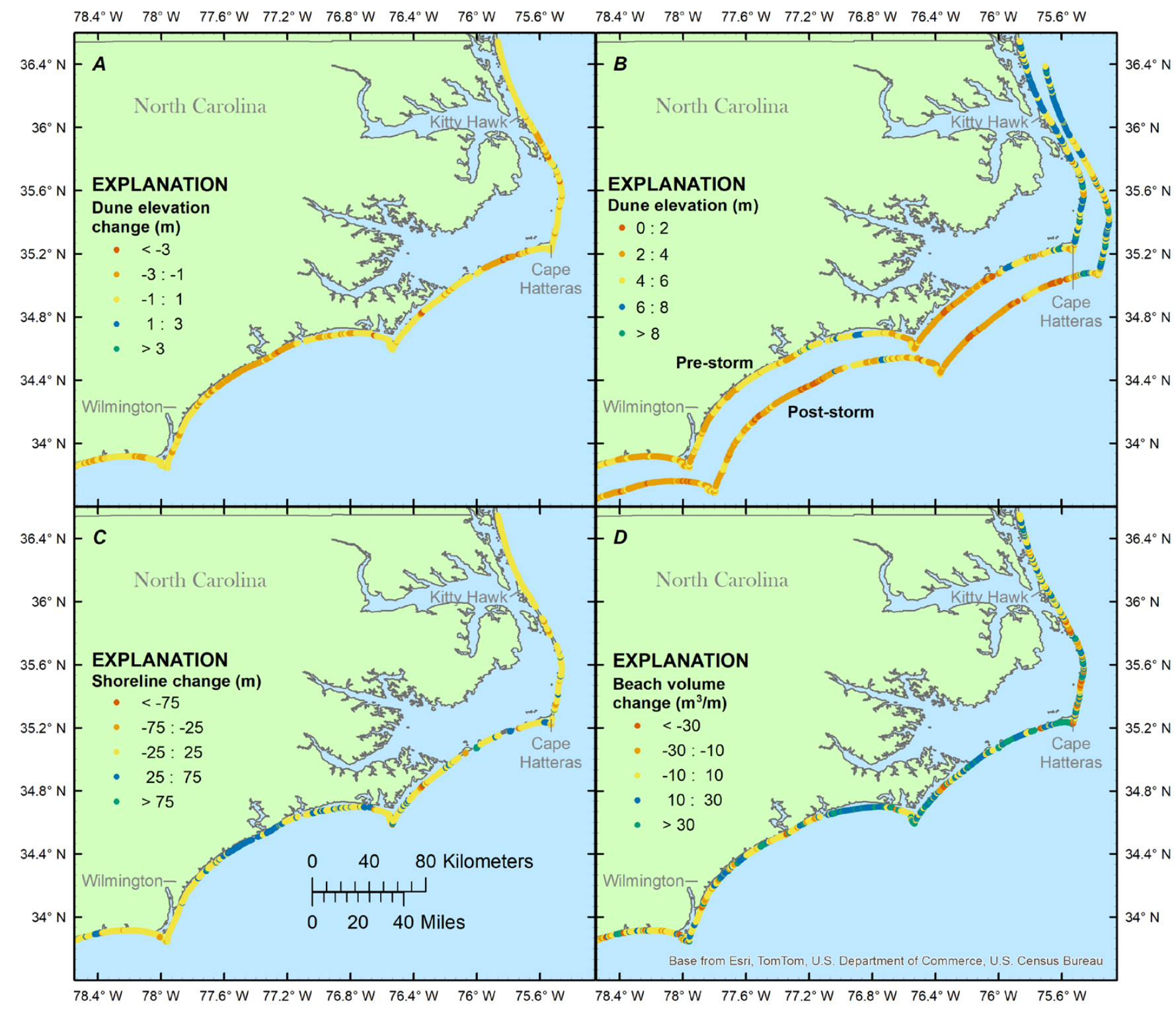

Figure 23. Maps showing Hurricane Matthew $(A)$ dune elevation change, $(B)$ pre- and post-storm dune elevation, $(C)$ shoreline change, and $(D)$ beach volume change between January 2014 and November 2016 for the North Carolina coast. 


\section{Conclusion}

After Hurricane Mathew, as a part of the National Assessment of Coastal Change Hazards project, the USGS collected post-storm oblique aerial photography and conducted lidar topographic surveys to document the changes that resulted from the storm. Comparisons of post-storm photographs with those collected prior to Matthew's landfall were used to characterize the nature, magnitude, and spatial variability of hurricane-induced coastal changes. The complete library of pre- and post-Matthew photographs is available online. Analysis of pre- and post-storm lidar elevations were used to quantify magnitudes of changes in shoreline position, dune elevation, and beach volume. Extensive erosion was observed along the entire study area from Florida to North Carolina. Complex spatial variability in the response can be attributed to a variety of factors, including, but not limited to, coastal geomorphology, offshore geology, nearshore processes, and development density. Further analysis of these data can allow for a greater understanding of the observed patterns of change. Additionally, the data can be used to verify the accuracy of pre-landfall coastal change predictions and refine and improve the models for use in future storms. 


\section{References Cited}

Doran, K.S., Long, J.W., Birchler, J.J., and Tiling-Range, Ginger, 2017, Hurricane Matthew overwash extents: U.S. Geological Survey data release, accessed May 4, 2018, at https://doi.org/10.5066/F7W09433.

Doran, K.S., Long, J.W., Birchler, J.J., Brenner, O.T., Hardy, M.W., Morgan, K.L.M, Stockdon, H.F., and Torres, M.L., 2017, Lidar-derived beach morphology (dune crest, dune toe, and shoreline) for U.S. sandy coastlines: U.S. Geological Survey data release, accessed March 8, 2018, at https://doi.org/10.5066/ F7GF0S0Z.

Doran, K.S., Plant, N.G., Stockdon, H.F., Sallenger, A.H., and Serafin, K.A., 2009, Hurricane Ike-Observations and analysis of coastal change: U.S. Geological Survey Open-File Report 2009-1061, 35 p., accessed November 9, 2018 at https://pubs.usgs.gov/of/2009/1061/.

Florida Department of Environmental Protection, 2017, Hurricane damage assessment report for 2016Florida's beaches and dunes: Tallahassee, Fla., Division of Water Resource Management, Florida Department of Environmental Protection, 55 p., accessed April 2, 2018, at https://floridadep.gov/water/engineering-hydrology-geology/documents/hurricane-damage-assessment-report-2016-florida\%E2\%80\%99s.

Frantz, E.R., Byrne, M.J., Sr., Caldwell, A.W., and Harden, S.L., 2017, Monitoring storm tide and flooding from Hurricane Matthew along the Atlantic coast of the United States, October 2016: U.S. Geological Survey Open-File Report 2017-1122, 37 p., accessed July 13, 2018, at https://doi.org/10.3133/ ofr20171122.

McCallum, B.E., Wicklein, S.M., Reiser, R.G., Busciolano, Ronald, Morrison, Jonathan, Verdi, R.J., Painter, J.A., Frantz, E.R., and Gotvald, A.J., 2013, Monitoring storm tide and flooding from Hurricane Sandy along the Atlantic coast of the United States, October 2012 (revised April 2013): U.S. Geological Survey Open-File Report 2013-1043, 42 p., accessed July 13, 2018, at https://doi.org/10.3133/ ofr20131043.

Morgan, K.L.M., 2015, Baseline coastal oblique aerial photographs collected from Key Largo, Florida, to the Florida/Georgia border, September 5-6, 2014: U.S. Geological Survey Data Series 953, accessed April 3, 2018, at https://doi.org/10.3133/ds953.

Morgan, K.L.M., 2017a, Winter 2016, part A-Coastal oblique aerial photographs collected from the South Carolina/North Carolina border to Assateague Island, Virginia, February 18-19, 2016: U.S. Geological Survey Data Series 1029, accessed April 3, 2018, at https://doi.org/10.3133/ds1029.

Morgan, K.L.M., 2017b, Post-Hurricane Matthew coastal oblique aerial photographs collected from Port St. Lucie, Florida, to Kitty Hawk, North Carolina, October 13-15, 2016: U.S. Geological Survey data release, accessed April 3, 2018, at https://doi.org/10.5066/F7154F67.

Morgan, K.L.M., 2017c, Baseline coastal oblique aerial photographs collected Ponte Vedra, Florida, to South Carolina/North Carolina border, August 24, 2011, U.S. Geological Survey data release, accessed April 3, 2018, at https://doi.org/10.5066/F7N877XX.

Plant, N.G., Holland, K.T. and Puleo, J.A., 2002, Analysis of the scale of errors in nearshore bathymetric data: Marine Geology, v. 191, nos. 1-2, p. 71-86, accessed March 13, 2018, at https://doi.org/10.1016/ s0025-3227(02)00497-8.

Powell, M.D., Houston, S.H., Amat, L.R., and Morisseau-Leroy, Nirva, 1998, The HRD real-time hurricane wind analysis system: Journal of Wind Engineering and Industrial Aerodynamics, v. 77-78, September, p. 53-64, accessed March 13, 2018, at https://doi.org/10.1016/s0167-6105(98)00131-7.

Sallenger, A.H., Jr., 2000, Storm impact scale for barrier islands: Journal of Coastal Research, v. 16, no. 3, p. 890-895, accessed March 13, 2018, at http://journals.fcla.edu/jcr/article/view/80902/78046. 
Stewart, S.R., 2017, National Hurricane Center Tropical Cyclone Report-Hurricane Matthew: National Oceanic and Atmospheric Administration, National Hurricane Center Tropical Cyclone Report, AL142016, 96 p., accessed June 29, 2017, at https://www.nhc.noaa.gov/data/tcr/AL142016_Matthew.pdf.

Stockdon, H.F., Doran, K.S., and Sallenger, A.H., Jr., 2009, Extraction of lidar-based dune-crest elevations for use in examining the vulnerability of beaches to inundation during hurricanes: Journal of Coastal Research Special Issue, v. 53, November, p. 59-65, accessed March 13, 2018, at https://doi.org/10.2112/ SI53-007.1.

Stockdon, H.F., Doran, K.S., Thompson, D.M., Sopkin, K.L., Plant, N.G., and Sallenger, A.H., 2012, National assessment of hurricane-induced coastal erosion hazards - Gulf of Mexico: U.S. Geological Survey Open-File Report 2012-1084, 51 p., accessed March 13, 2018, at https://doi.org/10.3133/ ofr20121084.

Stockdon, H.F., Holman, R.A., Howd, P.A., and Sallenger, A.H., Jr., 2006, Empirical parameterization of setup, swash, and runup: Coastal Engineering, v. 53, no. 7, p. 573-588, accessed March 13, 2018, at https://doi.org/10.1016/j.coastaleng.2005.12.005.

Stockdon, H.F., Sallenger, A.H., Jr., Holman, R.A., and Howd, P.A., 2007, A simple model for the spatially-variable coastal response to hurricanes: Marine Geology, v. 238, no. 1-4, p. 1-20, accessed March 13, 2018, at https://doi.org/10.1016/j.margeo.2006.11.004.

Stockdon, H.F., Sallenger, A.H., Jr., List, J.H., and Holman, R.A., 2002, Estimation of shoreline position and change using airborne topographic lidar data: Journal of Coastal Research, vol. 18, no. 3, p. 502-513, accessed March 13, 2018, at http://journals.fcla.edu/jcr/article/view/81307/78447.

Weber, K.M., List, J.H., and Morgan, K.L.M., 2005, An operational mean high water datum for determination of shoreline position from topographic lidar data: U.S. Geological Survey Open-File Report 2005-1027, accessed March 13, 2018, at https://pubs.usgs.gov/of/2005/1027. 
욜

蒠

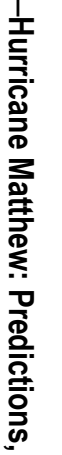

웅

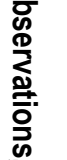

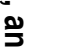

흥

$\stackrel{2}{=}$

常

응

\&̊ำ

홍

㥯

p

옹

के

兽

웅

容 